\title{
Foreign Portfolio Investors before and during a Crisis
}

Woochan Kim and Shang-Jin Wei

CID Working Paper No. 6

March 1999

(C) Copyright 1999 Woochan Kim, Shang-Jin Wei, and the President and Fellows of Harvard College

\section{Working Papers Center for International Development at Harvard University}




\title{
Foreign Portfolio Investors before and during a Crisis
}

\author{
Woochan Kim and Shang-Jin Wei*
}

\begin{abstract}
Using a unique data set, we study the trading behavior of foreign portfolio investors in Korea before and during the currency crisis. Different categories of investors have significant differences as well as similarities. First, non-resident institutional investors are always positive feedback traders, whereas resident investors before the crisis were negative feedback (contrarian) traders but switch to be positive feedback traders during the crisis. Second, individual investors herd significantly more than institutional investors. Non-resident (institutional as well individual) investors herd significantly more than their resident counterparts. Third, differences in the Western and Korean news coverage are correlated with differences in net selling by nonresident investors relative to resident investors.
\end{abstract}

Key words: foreign portfolio investment, crisis, feedback trading, herding JEL classification: F21, F3, G15

Shang-Jin Wei is Associate Professor of Public Policy, Harvard University and Faculty Research Fellow, National Bureau of Economic Research.

Woochan Kim, currently Ph.D student at Harvard University's Kennedy School, was formerly an official at the Ministry of Finance of the Republic of Korea.

\footnotetext{
*Acknowledgement: We thank Chul-Hee Park at the Korea Securities Computer Corporation (KOSCOM) for kindly providing the investor position and stock data sets, Rick Imai, Mike Kennedy, Richard Zeckhauser and seminar participants at the OECD, University of California-Davis, and Harvard University for helpful comments, and Greg Dorchak for editorial assistance. Part of the paper was written when SJ Wei was visiting the OECD. The views in the paper are the authors' own, and may not be shared by any organization they are or have been associated with. Correspondence may be sent to: Prof. Shang-Jin Wei, Kennedy School of Government, Harvard University, 79 JFK Street, Cambridge, MA 02138, USA. Or email to shang-jin_wei@ harvard.edu.
} 


\title{
Foreign Portfolio Investors before and during a Crisis
}

\author{
Woochan Kim and Shang-Jin Wei
}

\section{Introduction}

In the context of recent Asian financial crisis, it has been alleged that foreign portfolio investors may have been positive feedback traders (e.g., rushing to buy when the market is booming and rushing to sell when the market is declining), and eager to mimic each other's behavior ignoring information about the fundamentals. Behaviors such as these could have exacerbated the crisis to an extent not otherwise warranted by economic fundamentals. Understanding foreign investors' behavior is also relevant for the discussion on the desirability of capital controls. Careful statistical documentation of investor trading behavior to prove or disprove these hypotheses has been relatively lacking. But the hypothesis can be connected with an emerging literature on behavioral finance, mostly in the domestic finance context. For example, it has been argued that individual investors'trading is often driven by irrational, sentimental shocks (for example, see Lee, Shleifer and Thaler, 1990 and 1991 for an explanation of the discounts on the closed-end funds). As another example, again using evidence from domestic market data, it has been argued that institutional investors often exhibit herding behavior, though the tendency is quantitatively small (see Lakonishok, Shleifer and Vishny, 1992). There are also theoretical models in which there are irrational noise traders, and rational investors pursue positive feedback strategies, destabilizing the prices in the process (De Long, Shleifer, Summers, and Waldmann, 1990).

In this paper, we aim to provide an account of the behavior of foreign portfolio investors before and during a crisis. We distinguish between institutional versus individual investors, and between those who reside in the emerging market in question (with potentially more information about the fundamentals) and those outside. We examine how the behavior of each type of foreign investors may have evolved from the pre-crisis to the crisis periods. We also investigate how they may have reacted to the news about the emerging market in question. We make use of 
a unique data set that details monthly positions of every foreign investor in every stock in the Korean stock market from December 1996 to June 1998.

Frankel and Schmukler $(1996,1998)$ have examined an important aspect of portfolio investment in emerging markets, namely, possible informational asymmetry between domestic and international investors. But their data set (prices of closed end country funds and their corresponding net asset values) does not allow them to distinguish between institutional versus individual investors, or to investigate possible momentum trading or herding behavior.

Choe, Kho, Stulz (1998) use transaction data on the Korean stock market (December, 1996 to December, 1997) to examine the effect of foreign investor trading on the Korean stock price. They find evidence of foreign investors engaging in positive feedback trading and herding, but the evidence becomes weaker or insignificant in the last three months of their sample. Furthermore, they find that the foreign investor-initiated trades are associated with abnormal returns only in a narrow window (say ten minutes) of time around the trade.

Our paper is different from theirs in a number of ways. First, the two data samples are different. While their data is of much higher frequency than ours, the buy and sell trades in their sample are not associated with an investor ID. Thus, in their paper, to compute the herding measures, each buy- or sell-trade has to be assumed to originate from a separate investor. As they acknowledged, this assumption could induce upward bias in the computed herding statistics since the same investor could have executed multiple trades (likely in the same direction) in a given period of time. In our sample, as every investor's position is identified by a unique ID number, we do not have to make this assumption, and can presumably obtain more accurate herding statistics.

Second, their paper does not separate foreign institutional versus foreign individual investors, which we do. Indeed, we find some systematic differences in the trading behavior between the two groups. Third, our data which extends to the end of June, 1998, allows for a better comparison of the differences in trading behavior before and during the crisis (at least for trading patterns involving monthly frequency). We think November 1997 is a reasonable month to mark the beginning of the crisis (to be explained below). We have eight months of data since the crisis broke in Korea as compared with their two months of (transaction data). For example, in contrast to their finding, we find fairly strong evidence of continued herding and positive 
feedback trading during the crisis. Furthermore, institutional traders residing in Korea have switched from negative feedback traders before the crisis to positive feedback traders during the crisis.

The paper is organized as follows. Section 2 describes our data sets. Sections 3, 4, and 5 examine three aspects of foreign investor behavior, respectively: feedback trading, herding, and reaction to news. Section 6 offers some concluding remarks.

\section{Data}

In this paper, we make use of three data sets.

\section{$2.1 \quad$ Investor Position Data}

For each investor, identified by an ID code, this data set contains following information, among others: (i) month-end share holding for each stock listed in the Korea Stock Exchange (KSE), (ii) nationality, (iii) residence, (iv) type (e.g. individual or institutional), and (v) whether the investment ceiling is binding or not for that investor in that month. For confidentiality reasons, only the codes but not the names of the investors are available.

The data set spans from December 1996 to June 1998. On November 18, the Bank of Korea gave up defending the Korean Won. And on November 21, the Korean government asked the IMF for a bail out. Hence, we regard November, 1997 as when the crisis began. By this criterion, our data covers ten months before the crisis and eight months during the crisis.

The data set was kindly provided by the Korea Securities Computer Corporation (KOSCOM), an affiliate to the Korea Stock Exchange (KSE). The position data by investor and by stock is hard to come by in general. In our case, the Korean restriction on foreign ownership of domestic stocks and the need to enforce it helps to make this data available. ${ }^{1}$

\footnotetext{
${ }^{1}$ For example, between May and November 1997, foreign investors, in aggregate, could not own more than $23 \%$ of the outstanding shares per company and foreign investors, individually, could not own more than $6 \%$. Since May 1998, there exists no restriction on foreign ownership, except for two listings (POSCO and KEPCO). Upper ceiling on foreign investors in aggregate changed from 10\% (Jan, 1992) $\rightarrow 12 \%(\mathrm{Dec}, 1994) \rightarrow 15 \%(\mathrm{Jul}, 1995) \rightarrow 18 \%$ $($ Apr, 1996) $\rightarrow 20 \%$ (Oct, 1996) $\rightarrow 23 \%$ (May, 1997) $\rightarrow 26 \%$ (Nov, 1997) $\rightarrow 55 \%$ (Dec, 1997) $\rightarrow$ 100\% (May, 1998). As for individual foreign investor, the upper ceiling changed from 3\% (Jan, 1992) $\rightarrow$ 4\% (Apr, 1996) $\rightarrow 5 \%$ $($ Oct, 1996) $\rightarrow 6 \%$ (May, 1997) $\rightarrow 7 \%($ Nov, 1997) $\rightarrow 50 \%($ Dec, 1997) $\rightarrow 100 \%$ (May, 1998).
} 


\subsection{Stock Data}

For each stock, we collect information on (i) month-end price, (ii) month-end number of shares outstanding, (iii) monthly transaction volume (and value), and (iv) whether the investment ceiling is binding or not in that month. In addition, we also collect information on the Korea Composite Stock Price Index (KOSPI) from KOSCOM and month-end Won/dollar exchange rate from the Federal Reserve Board's website.

Figures 1 and 2 plot the exchange rate (US dollar/1,000 Won) and the stock market price index (KOSPI), respectively. Combining the two pieces of information, Figure 3 traces the dollar value of a \$100 investment in KOSPI on January 1, 1997 throughout the sample (to June 30, 1998).

\section{$\underline{2.3 \quad \text { News }}$}

To examine foreign investors' reaction to news, we have constructed a data set on the numbers of good and bad news on the Korean economy, by source and by month. It is constructed by searching five daily newspapers (Wall Street Journal, Financial Times, New York Times, Washington Post, and Korea Herald) using Dow-Jones Interactive and Lexis-Nexis. Details on filtering and labeling are explained in Section 5.

\section{Positive Feedback Trading}

There are concerns that international portfolio investors may be positive feedback traders, and that positive feedback traders could destabilize the market. Positive feedback trading pattern is one with which one buys securities when the prices rise and sells when the prices fall. This trading pattern can result from extrapolative expectations about prices, from stop-loss orders -automatically selling when the price falls below a certain point, from forced liquidations when an investor is unable to meet her margin calls, or from a portfolio insurance investment strategy which calls for selling stocks when the price falls and buying it when the price rises.

Positive feedback trading can destabilize the market by moving asset prices away from the fundamentals. At least since Friedman (1953), many economists believe that positive feedback traders cannot be important in market equilibrium as they are likely to lose money on 
average. This view has been challenged in the last decade or so. De Long, Shleifer, Summers, and Waldmann (1990) argued that in the presence of noise traders, even rational investors may want to engage in positive feedback trading, and in the process destabilizes the market.

Empirical examination of this issue has emerged recently. Using quarterly data on U.S. pension funds in the U.S. market, Lakonishok, Shleifer, and Vishny (1992, LSV for short in later reference) did not find evidence of significant amount of positive feedback trading. On the other hand, using transaction-level data, Choe, Kho, and Stulz (1998) do find evidence that foreign investors as a group engage in positive feedback trading in Korea.

This paper goes beyond the earlier studies. We decompose the universe of foreign investors alone two different dimensions (i.e. into four different cells). First, we dissect them into institutional versus individual investors. Along the second, we distinguish those residing in Korea versus those outside. As a further extension, we separate non-resident foreign investors into U.S. investors, Asian investors, and the rest.

\section{Methodology and sample construction}

The objective is to examine the connection between the trading behaviors of the investors (within a given sub-group) and the previous month performance of the stocks. We examine the connection for three time periods: the whole sample (January, 1997 - June, 1998), the pre-crisis period (January, 1997-October, 1997), and the in-crisis period (November, 1997-June, 1998).

Within each time period, we form five approximately equally sized (in terms of stockmonths) portfolios based on the previous month performance of the stocks. The performance of a stock is defined as the return of the stock in excess of the market return, minus the depreciation of the Korean won exchange rate against the U.S. dollar. That is, the return for a particular stock from month t-1 to month $\mathrm{t}$ is $\left[\ln \left(P_{t}\right)-\ln \left(P_{t-1}\right)\right]-\left[\ln \left(K O S P I_{t}\right)-\ln \left(K O S P I_{t-1}\right)\right]-\left[\ln \left(S_{t}\right)-\ln \left(S_{t-1}\right)\right]$, where $P_{t}, K O S P I_{t}$, and $S_{t}$ are the price of the stock (stock subscript omitted), KOSPI index, and Won/\$ exchange rate at time $t$.

Following LSV (1992), we employ two measures of investors' trading direction: a scaleadjusted net purchase and a buyers' ratio: 
(1) Scale - adjusted Net Purchase $=\frac{\text { Number of Shares Purchased }- \text { Number of Shares Sold }}{\text { Number of Shares Purchased }+ \text { Number of Shares Sold }}$

$$
\text { Buyers' Ratio }=\frac{\text { Number of Buyers }}{\text { Number of Buyers }+ \text { Number of Sellers }}
$$

The first measure describes the net purchase (scaled by the total trading). The denominator (the scale adjustment) makes sure that a large purchase does not receive more weights than a small purchase. The second measure is constructed to check the robustness of the finding to the possibility that a few very large investors dominate the net purchase numbers.

To avoid possible biases in quantifying the trading behavior, we exclude certain observations (investors or stock-month). First, investors who are registered after December 31, 1996 are dropped because their entrance to the market could show up only as a buy. Second, investors who declare their purpose of the stock purchase as direct investment are excluded because they do not engage in active trading. Third, stocks that have reached foreign ownership limit are dropped because any change in the net position of the foreign investors as a whole has to be a sell to Korean investors. Fourth, observations (stock-month) involving stocks not initially owned by any foreign investors are also excluded.

\section{$\underline{\text { Results and Interpretations }}$}

Table 2 reports the basic finding using scale-adjusted net purchase as a measure of trading direction. For the entire sample period (97.1-98.6) (the top panel) and for foreign investors as a whole, there is a net sell for each portfolio. However, comparing across the five portfolios, one sees clearly that foreign investors sell worst performers (in terms of the previous-month returns) much more aggressively than the best performers. Indeed, in the sixth row, we report a formal ttest on difference between the mean purchase of the best performing portfolio (stocks in row 5) and that of the worst performing portfolio (stocks in row 1). The standard errors are reported in parenthesis $^{2}$. We see the difference is positive and statistically significant. This is consistent with the view that investors as a whole for the whole sample period are positive feedback traders (although they only sell the best recent performing stocks less aggressively rather than buy them). 
Looking only at the universe of foreign investors for the whole sample period masks important differences in trading patterns in different time periods across different sub-groups of investors. The middle and lower two panels look at the trading behavior during the pre-crisis and the in-crisis periods separately. In each panel, the third and fourth columns decompose foreign investors into those residing in Korea and those outside. In the last three columns, non-resident investors are further decomposed into Asian, American, and other investors.

It is worthwhile to highlight some key findings. (1) Before the crisis broke out in November, 1997, the resident institutional traders in fact sell the recently best performing stocks, and buy the recently worst performing stocks. The mean difference in the net purchase between the two portfolios is -0.183 and statistically significant at the five percent level. Thus, they are negative feedback (or contrarian) traders. (2) In the pre-crisis period, it is the non-resident institutional investors (whether they are in the U.S., Asia, or elsewhere) who are positive feedback traders. (3) In the pre-crisis period, resident individual investors may also be negative feedback traders, although the evidence is not statistically significant.

(4) During the crisis, non-resident institutional traders' tendency to engage in positive feedback trading (i.e., selling recent worse performers more aggressively) is reinforced. (5) On the other hand, resident foreign institutions and resident foreign individuals have switched to become positive feedback traders themselves, although the evidence on this is less strong.

As a robustness check (against the possibility of a few large trades executed by a small number of investors), Table 3 reexamines this issue using buyers' ratio as a measure of foreign investors' trading direction but otherwise replicating the reporting format. The results are broadly similar as before. In particular, all of the five findings stated before remain to be true in Table 3.

Certain type of positive feedback trading pattern can be an artifact of coincidence. For example, economic reforms that generally improve the stock returns ${ }^{3}$ in that country can occur simultaneously as the country liberalizes its policies on capital inflows. In this case, foreign capital inflows can appear to follow a rise in (market-wide) stock returns. It is useful to note that the type of positive feedback trading investigated in this paper is across stocks within a given market, and hence cannot be explained by this logic.

\footnotetext{
${ }^{2}$ The same reporting format is used for all sub-groups of investors in all time periods.
} 
Another possible defense is that foreign investors (residing abroad) maybe informationally disadvantaged relative to domestic investors. They may take a (relatively greater) decline in the price of a particular stock as unfavorable news revealed by domestic investors, and may therefore rationally choose to sell it (more aggressively relative to other stocks) (See Brennan and Cao, 1997, for such a model). It may be useful to check if the positivefeedback trading pattern in our sample is ex post profitable. We do it in two steps. First, in each month, we form an equally-weighted portfolio of ten best performing stocks, and another equally-weighted portfolio of ten worst performing stocks, based on the previous month's return as defined above for Tables 2 and 3. The average returns of the two portfolios in the previous months are reported in the first row of each of the three panels (representing three different periods) in Table 4 (labeled as "horizon -1"). Second, we track their performances over the subsequent six months. The results are reported in the other rows of Table 4 (labeled as "horizons 1-6"). We perform a difference in mean test (mean return of the past winners minus that of the past losers) and find that the difference is negative for all six horizons under investigation. The difference is statistically significant for the one- and two-month horizons at the ten percent level. In another words, the data suggest that the relative ranking of stock performance reverses itself in the sample. On average, if one has to choose between a negative and a positive feedback trading strategy, the former would have been profitable, at least at the one- or two-month horizon. The excess return is quantitatively large at a $9 \%$ monthly rate.

As a robustness check, we also form equally-weighted portfolios of 30 best performing stocks and 30 worst performing (based on previous-month's returns). The results are reported in the right half of Table 4. For these enlarged portfolios, again, there is reversal in the ranking of relative performance. In fact, the recent past losers outperform the recent winners, in a statistically significant and quantitatively large way, over one-month, two-month, and so on, all the way to five-month horizons. Again, a contrarian trading strategy rather than a positive feedback one would have been profitable. As qualifications, we note that our tests have not adjusted for risk levels of the stocks, and do not preclude the possibility that a positive feedback trading strategy could be profitable within a day or for horizons longer than six months.

\footnotetext{
${ }^{3}$ Bekaert and Harvey (1998) and Henry (1997) for evidence on this.
} 


\section{Herding}

Herding is the tendency that investors of a particular group mimic each other's trading. Portfolio investors may herd rationally or irrationally. Informational asymmetry may cause uninformed but rational speculators to choose to trade in the same way as informed traders (Bikhchandani, Hirshleifer and Welch, 1992; and Banerjee, 1992). Since informational problem may be more serious when it comes to investing in a foreign market than the domestic one, herding may be more severe correspondingly.

This logic suggests that (1) individual investors may herd more than the institutions as the latter may have more resources to assemble and process information about a foreign market; and (2) non-resident investors may herd more than resident foreign investors assuming the latter have more timely information about the country they live in.

There is an alternative explanation for herding among institutional investors. Unlike individual investors, fund managers face regular reviews (e.g., quarterly for mutual funds, and annually for pension funds) on their performance relative to a benchmark and/or to each other. This may induce them to mimic each other's trading to a greater extent than they otherwise would (See Scharfstein and Stein, 1990). This logic suggests an opposite prediction from the informational asymmetry story, that (1) institutional investors may herd more than individual investors, and that (2) there is no presumption to argue for greater herding for non-resident institutional investors than their resident counterparts (assuming both face the same regular relative performance comparisons).

There have been several empirical papers that quantify herding behavior. Using data on institutional investors, the pioneering paper by Lakonishok, Shleifer, and Vishny (or LSV, 1992), followed by work by Grinblatt, Titman, and Wermers (1995), and Wylie (1997), all report evidence of herding among US or UK institutional investors. Using data on foreign investors (or U.S. investors) in Korea as a single group, Choe, Kho, and Stulz (1998) find evidence of herding. None of the previous papers that we are aware of compares different herding tendencies by different investor types on data from a single source, which is the central focus of this section of our paper. 


\section{Methodology and Sample Construction}

We employ the herding indices proposed by LSV (1992) but construct the sample in a way that takes into account the Wylie (1997) correction for possible bias induced by short-selling constraint. Let $B(i, j, t)$ be the number of investors in group $i$ that have increased the holdings of stock $j$ in month $t$ (i.e., number of net buyers), and $S(i, j, t)$ the number of investors in group $i$ that have decreased the holdings of stock $j$ in month $t$ (number of net sellers). Let $p(i, t)$ be the number of net buyers in group $i$ aggregated across all stocks in month $t$ divided by the total number of active traders (number of net buyers plus number of net sellers) in group $i$ aggregated across all stocks in month $t$. Then, $H(i, j, t)$ is defined as the herding index for investors in group i, on stock $j$, in month $t$.

$$
\begin{aligned}
& H(i, j, t)=\left|\frac{B(i, j, t)}{B(i, j, t)+S(i, j, t)}-p(i, t)\right|-E\left|\frac{B(i, j, t)}{B(i, j, t)+S(i, j, t)}-p(i, t)\right| \\
& p(i, t)=\frac{\sum_{j=1}^{N} B(i, j, t)}{\sum_{j=1}^{N} B(i, j, t)+\sum_{j=1}^{N} S(i, j, t)}
\end{aligned}
$$

$$
\begin{aligned}
& H(i, t)=\frac{1}{N} \sum_{j=1}^{N} H(i, j, t) \\
& H(i)=\frac{1}{N T} \sum_{t=1}^{T} \sum_{j=1}^{N} H(i, j, t)
\end{aligned}
$$

$\mathrm{H}(\mathrm{i}, \mathrm{t})$ is the herding index for group $\mathrm{i}$ in month $\mathrm{t}$, averaged across all stocks. $\mathrm{H}(\mathrm{i})$ is the herding index for group $\mathrm{i}$, averaged across all months in the sample. In the definition of $\mathrm{H}(\mathrm{i}, \mathrm{j}, \mathrm{t})$, $p(i, t)$ is subtracted to make sure that the resulting index is insensitive to general market conditions (i.e., a bull or bear market). By taking absolute values, the first term in equation (1) captures how much of the investment is polarized in the direction of either buying or selling. The second term in equation (1), also called as adjustment factor, is subtracted to correct for the mean value of the first term under the assumption of no herding. ${ }^{4}$ The second term can be

\footnotetext{
${ }^{4}$ Also, the adjustment factor [the second term in equation (1)] is a decreasing function of the number of traders
} 
computed under the assumption that $B(i, j, t)$ follows a binomial distribution. Note that for large $\mathrm{N}$ and $\mathrm{T}, H(i, t)$ and $H(i)$ follow normal distributions by the central limit theorem.

To avoid any possible bias in computing the herding indices, we exclude certain investors and observations (stock-month) from our sample. Like the sample we have constructed to examine positive feedback trading, we exclude here (1) investors that are registered after December 31, 1996, (2) investors who buy stocks for direct investment purpose, (3) stockmonths for which the foreign ownership limit is reached, and (4) stock-months for which the stocks are not owned by foreign investors in the previous month. The last exclusion is motivated by the short-selling constraint. When short selling is not allowed, any trade on that stock would have to first show up as a buy, thus biasing the herding index upward (Wylie, 1997). Finally, if a stock in a given month is traded by only one foreign investor in that group, that observation is dropped.

\section{$\underline{\text { Results and Interpretations }}$}

The basic results are presented in Table 5. For each investor group i and sample period, we report the corresponding herding statistics, H(i), with standard errors in the parenthesis below. Then we perform a sequence of difference-in-mean tests between individual and institutional investors (reported in Rows 4, 8, and 12), between pre-crisis and in-crisis periods for any given group of investors (reported in Rows 13-15), and between non-resident and resident investors of any given group (reported in Column 4).

A number of patterns stand out. First, almost all groups of foreign investors exhibit positive herding statistics that are statistically significant. The only possible exception is the set of resident institutional investors.

Second, individual investors' herding statistics (about 0.11 ) are nearly twice as large as those of the institutional investors (between 0.05 and 0.06). This is true before the crisis as well as during the crisis. It is true whether we look at those residing in Korea or those outside (Rows 4,8 , and 12 of Table 5).

active $[B(i, t)+S(i, t)]$. 
Third, non-resident institutional investors or non-resident individual investors always herd more than their resident counterparts. This is again true during the crisis as well as before (Column 4).

Fourth, from the pre-crisis to the in-crisis periods, there is no statistically significant change in the herding tendency of individual investors, whether they are resident or non-resident. In comparison, for institutional investors as a whole, there is statistically significant increase in the herding statistics (the cell in Row 15/Column 1). On the other hand, within the set of the institutional investors, the increase in the herding statistics, while positive, is not statistically significant at the ten percent level, either for the subset of the non-residents alone or for the subset of residents alone (the cells in Row 15/Columns 2-3). The combination of the results on the institutional investors probably suggests that during the crisis period, there is an increase in the similarity of trading between the resident and non-resident subgroups, though not within each subgroup.

Within the set of non-resident foreign investors, we have also computed herding statistics for various subsets of Asian and U.S. investors (not reported to save space) before and during the crisis. Before the crisis, the U.S. investors (as a whole, the subset of institutions, or the subset of individuals) herd more than their Asian counterparts. During the crisis, however, the difference between the U.S. and Asian investors have disappeared.

The findings that individual investors herd more than institutions and that non-residents herd more than the residents are consistent with the theory that herding is induced by informational asymmetry. At the same time, the contrast between institutional investors (who are subject to regular relative performance evaluations) and individuals (who are not) suggests that the incentive to herd driven by the relative performance review considerations is probably not the dominant feature of the data.

Our results on the relative herding tendencies help to explain an observation made by Choe, Kho, and Stulz (1998): the herding statistics for the universe of foreign investors (which includes individuals and non-resident investors) are much larger than those for U.S. mutual funds reported by Wermers (1998). 


\section{Ex post Rationality}

Herding indices essentially measure the degree of correlation in trading behaviors among investors in a given group. As such, they do not by themselves distinguish between two possibilities: that investors intentionally (rationally or not) mimic each other's trading, versus that investors respond to common information about the fundamentals.

To distinguish between the two is difficult which is probably why previous empirical papers do not do this. We decide to provide some suggestive evidence here by examining ex post rationality of the herding behavior in our sample. If the high values of herding statistics in our sample simply reflect the fact that the investors are responding to common information and these information are return-relevant, then, we would expect that those stocks that the investors herd more aggressively should yield abnormal returns (relative to those stocks they do not herd as much).

Let $R_{j t+1}$ denote the return of stock $j$ from $t$ to $t+1$ in excess of the KOSPI return minus the won exchange rate depreciation. Let $H_{j t}$ denote LSV herding index for stock $j$ in month $t$, and $N P_{j t}$ the (scale-adjusted) net purchase of stock $j$ in month $t$. All three variables are defined for a given investor group, $i$, which we omit from the subscripts for simplicity. For each investor group, we run the following fixed effects regression:

$$
R_{j t+1}=\alpha+\alpha_{t}+\alpha_{k}+\left(\beta_{0}+\beta_{1} H_{j t}\right) N P_{j t}+\varepsilon_{j t}
$$

where $\alpha_{t}$ and $\alpha_{k}$ are time and industry dummies ${ }^{5}$. Under the null hypothesis that herding within a given group is the group's response to a common and return-relevant information, we would expect $\beta_{1}$ to be positive. We perform this regressions for both the one-month and three-month investment horizons. The results are reported in Table 6.

In overwhelming number of groups, we see that the estimates of $\beta_{1}$ are not different from zero, and sometimes with a negative sign. This is true for both the one-month and three-month horizons. The main exception for the one-month horizon is the group of non-resident institutions in the pre-crisis period. No group during the crisis has a positive $\beta_{1}$ that is statistically

\footnotetext{
${ }^{5}$ Due to computer capacity constraint, we use 67 industry dummies instead of over 600 stock dummies.
} 
significant. For the three-month horizon, the basic conclusion holds. The main exception is the subset of individual Asian non-resident investors during the crisis period. As a robustness check, we also use the buyers' ratio (as defined before) in place of the scale-adjusted net purchase, and obtain very similar findings (not reported to save space).

\section{$\underline{\text { Stock Characteristics and Herding }}$}

It may be useful to see if the degree of herding is related to a number of stock characteristics that are relatively easy to be observed by foreign investors. The first characteristic we examine is affiliation with the top five chaebols. Chaebols are family-run conglomerates that dominate the Korean corporate sector. The top five chaebols are Hyundai, Samsung, LG, Daewoo, and Sunkyong. Each of them invests in a diverse number of sectors, including cars, ships, and electronic equipment. There are 62 stocks in our sample that are affiliated with the top five chaebols.

Because each of the top chaebols permeates in many aspects of the economy, it invariably includes small-to-medium companies that are less known to foreign investors. Therefore, we also look at the second characteristic of the stock, whether they are reported on a daily basis in the Wall Street Journal's World Stock Market page. There are 19 stocks that fall into this group (see the explanation to Table 7 for a complete list of the 19 companies), two of which are not associated with any chaebols. (Obviously, there are 45 stocks in the sample that are affiliated with the top five chaebols, but not reported by the Wall Street Journal on a regular basis.)

We create two dummies, "Chaebol-5", and "WSJ-19", respectively for these two characteristics. Besides, we also look at the prior-month turnover of the stock, prior-month market capitalization, and prior month returns in excess of the KOSPI index. We also create a dummy for the crisis period (since November 1997).

For each of the four groups of foreign investors (resident individuals, resident institutions, non-resident individuals, and non-resident institutions), we regress the herding statistics on the stock characteristics discussed above. The results are reported in Table 7. [We have also performed regressions on various subset of stock characteristics. The results are not reported to save space.] In general, there is no evidence that any foreign investor group herd more on stocks associated with the top five chaebols. In comparison, there is statistically significant evidence 
that non-resident institutional investors (but not other groups) do herd more on stocks reported regularly in the Wall Street Journal, and on stocks that have more extreme returns in the previous month. Note that these results are obtained after we control for liquidity (proxied by turnover) and size (measured by market capitalization) of the stocks.

\section{Reaction to News}

Informational asymmetry is a fundamental problem in financial markets. As noted, it is likely to be more severe when it comes to investing in a foreign market. In this section, we make an attempt to examine whether resident and non-resident investors' trading difference can be linked to differences in their information sets.

We construct two news data sets by searching four major Western daily newspapers plus a Korean paper using Dow-Jones Interactive and Lexis-Nexis. The Western news set (labeled as Western-4) include Wall Street Journal (WSJ), Financial Times (FT), New York Times (NYT), Washington Post (WP). And the Korea news set is based on the Korea Herald (KH) -- the only major Korean paper that can be searched electronically throughout the sample ${ }^{6}$.

The news sets are constructed in three steps. First, for the four Western papers, we extract any article containing "Korea" and "Economy" in its headline or lead paragraph. For the Korean Herald, we obtain any article containing the word "Economy". Second, we apply a filter rule to the news: news that are of minor significance and that are not obviously good nor bad are dropped. Letters to the editors are also dropped while newspaper commentaries are kept. For the Western-4 news set, overlapping news on the same date are also dropped. Third, we count the number of good and bad news for each news set in each month. Generally speaking, any article containing the announcement of a liberalization measure, a restructuring effort, an IMF agreement or a foreign assistance program is regarded as good news $(\mathrm{G})$. Any article that reports new discovery of debt level, failure of major corporations, downgrade of bond ratings, depreciation of the Japanese yen, and the like is labeled as bad news (B). We avoid speculating on the general equilibrium effects of a given news but choose to follow the "conventional" wisdom at the time of the news. For example, the effect of an IMF program is controvertial ex

\footnotetext{
${ }^{6}$ For May and June, 1997, the Korea Economy Daily (KED) is used instead of KH due to problems of the Dow
} 
post, but was perceived as good news by the market according to newspaper reports at the time. As an illustration, Table 8 presents a subset of the news for the month of November, 1997.

We use the difference between the Western-4 and the Korean Herald as a measure of the difference in the information sets between non-resident and resident investors. Obviously, there is a big noise-to-signal ratio in this measure. First, the labeling of good versus bad news involves judgement. Second, investors potentially have many information sources in addition to these newspapers. Third, the simple count of good and bad news, adopted here for our data sets, is not likely to be accurate in describing the intensity of the news. Nonetheless, conversations with institutional fund managers indicate that many funds do not have staff in all the emerging markets they invest in, and often do not have the ability or time to process the information from local news sources. Precisely because our measure of informational asymmetry is very coarse, it would be all the more interesting if we find any association between the difference in trading behavior and the difference in news coverage.

In Table 9, Columns 4-7 report the news counts for the Western-4 and the Korean Herald, respectively. Columns 8 and 9 report the difference in the good and bad news (i.e., G-B) for the two news sets. Column (10) reports the difference between the Korean Herald and the Western-4 in terms of the good/bad news (which we could label as KH's relative-relative good news, or news gap).

There are some interesting difference in the reporting of the Korean economy. For example, we see that in the eight months leading up to November, 1997, the entries in Column 10 are all positive (or at least zero), meaning that the Western newspapers had been reporting relatively more bad news (or relatively less good news) as compared with the Korean Herald. In fact, in the month of November, 1997, when the foreign exchange crisis broke out, the four Western papers carried far more bad news (24) than good news (6). In contrast, the news in the Korean Herald was less skewed (11 bad news and 12 good news).

Immediately after the start of the crisis, from December, 1997, to February, 1998, the reverse became true. That is, the Korean Herald started to report relatively more bad news than the Western 4. Since March, 1998 to the end of the sample, the Western-4 would again report relatively more bad news.

Jones database. KED is not consistently available for the whole sample. 
In Columns 1 and 2 of Table 9, (scale-adjusted) net purchases by the U.S. non-resident investors and by all resident investors are reported. Column 3 reports the difference between the two (resident's net purchase minus that of the U.S. non-residents). The second to the last row reports the correlation between the resident's net purchase relative to that of the non-resident Americans (Column 3), and the Korean Herald's number of relative good news minus that of the Western-4 papers (Column 10). The correlation is 0.24 . The fact that it is positive is consistent with the hypothesis that the relative news received by non-resident U.S. investors may have influenced their net purchase (or sell) of the Korean stocks relative to the resident investors.

Similarly, we have tabulated the difference in net purchase by resident and non-resident individual investors, and that by resident and non-resident institutional investors (not reported to save space). Their correlations with the difference in news are 0.32 and 0.18 , respectively. Therefore, when the Western newspapers carry more bad news than the Korean paper, nonresident individuals or institutions, on average, tend to sell the Korean stocks more than their respective resident counterparts. The difference in the news coverage appears to have a greater impact on the trading patterns of the individuals.

The small number of the observations (18 months in total) and the noise in our news data set make it impossible to conduct any definitive test. Thus, our results should be interpreted with a big grain of salt.

\section{Concluding Remarks}

In this paper, we study foreign investors' trading behavior in the Korea Stock Exchange (KSE) during January 1997 - June 1998 using a unique data set that details every foreign investor's monthly stock positions.

There are a number of findings that are worth highlighting here. First, before the crisis broke out in November, 1997, those institutional investors inside Korea were contrarian (or negative feedback) traders (i.e. buying recent losers and selling recent winners). However, they switch to become positive feedback traders during the crisis period. In contrast, the non-resident institutional investors have been consistently engaged in positive feedback trading, and the

tendency is reinforced during the crisis period. Since the return data in the sample exhibits 
mean-reversion in horizons from one to six months, it appears that a negative feedback strategy would have been profitable ex post.

Second, individual investors herd significantly more than institutional investors. And non-resident investors (institutional as well as individual) herd significantly more than their resident counterparts. Herding may have slightly increased during the crisis period, but the change is largely insignificant. Furthermore, non-resident institutional investors herd more on the 19 stocks regularly reported in the Wall Street Journal, but not unusually so on stocks belonging to the top five Korean Chaebols. On an ex post basis, at least during the crisis period and without adjusting for risk, those stocks that the foreign investors herd to buy or herd to sell do not appear to carry abnormally positive or negative returns.

Third, major Western and Korean papers carry different numbers of good relative to bad news about the Korean economy. For example, in the months leading up to November, 1997, the Western papers reported relatively more bad news. This difference in news is correlated with the difference in the net selling of the Korean stocks by the non-resident investors relative to that of their resident counterparts. 


\section{References}

Banerjee, Abhijit (1992), “A Simple Model of Herd Behavior.” Quarterly Journal of Economics 107, pp. 797-817.

Bekaert, Greet, and Campbell Harvey, 1998, "Capital Flows and the Behavior of Emerging Market Equity Returns," Working Paper, Duke University.

Bikhchandani, Sushil, David Hirshleifer, and Ivo Welch (1992), “A Theory of Fads, Fashion, Custom, and Cultural Change as Information Cascades." Journal of Political Economy 100, pp. 992-1020.

Brennan, M. J. and H. Cao, 1997, "International Portfolio Investment Flows,” Journal of Finance 52: 1851-1880.

Choe, Hyuk, Bong-Chan Kho, and Rene M. Stulz (1998), "Do Foreign Investors Destabilize Stock Markets? The Korean Experience in 1997." NBER Working Paper No. 6661.

Frankel, Jeffrey A. and Sergio L. Schmukler (1996), “Country Fund Discounts, Asymmetric Information and the Mexican Crisis of 1994: Did Local Residents Turn Pessimistic Before International Investors?” NBER Working Paper No. 5714.

(1998), "Country Funds and Asymmetric

Information.” Policy Research Working Paper No. 1886, The World Bank.

Friedman, Milton (1953), "The Case for Flexible Exchange Rates," in Milton Friedman, ed. Essays in Positive Economics (University of Chicago Press, Chicago, IL).

Froot, Kenneth A., Paul G.J. O'Connell, and Mark S. Seasholes, "The Portfolio Flows of International Investors I." NBER Working Paper No. 6687.

Grinblatt, Mark, Sheridan Titman, and Russ Wermers (1995), “Momentum Investment Strategies, Portfolio Performance, and Herding: A Study of Mutual Fund Behavior." American Economic Review Vol. 85, pp. 1088-1105.

Henry, Peter, 1997, “Stock Market Liberalization, Economic Reform, and Emerging Market Equity Prices,'Unpublished working paper, MIT.

Kahneman, Daniel and Amos Tversky (1979), "Prospect Theory: An Analysis of Decision Under Risk.” Econometrica 46, pp. 171-185.

Lakonishok, Josef, Andrei Shleifer, and Robert Vishny (1992), “The Impact of Institutional Trading on Stock Prices.” Journal of Financial Economics Vol.32, pp. 23-43. 
Lee, Charles M.C., Andrei Shleifer, and Richard Thaler (1990), “Anomalies. Closed-End Mutual Funds." Journal of Economic Perspectives, Vol. 4, No. 4, pp. 153-164. (1991), "Investor Sentiment and the Closed-end Fund Puzzle."

Journal of Finance, Vol. 46, No. 1, pp. 75-109.

De Long, J. Bradford, Andrei Shleifer, Lawrence H. Summers, and Robert J. Waldmann (1990), "Positive Feedback Investment Strategies and Destabilizing Rational Speculation."

Journal of Finance, Vol. 45, No. 2, pp. 379-395.

Scharfstein, David S. and Jeremy C. Stein (1990), "Herd Behavior and Investment." American Economic Review 80, pp. 465-479.

Wermers, Russ (1995), "Herding, Trade Reversals, and Cascading by Institutional Investors." Working Paper, University of Colorado Boulder.

Wylie, Samuel (1997), "Tests of the Accuracy of Measures of Herding." Unpublished Paper. 


\section{Table 1a: Number of Foreign Investors by Type}

\begin{tabular}{|c|c|c|c|c|c|c|}
\hline & \multirow[t]{2}{*}{ All Investors } & \multirow{2}{*}{$\begin{array}{l}\text { Resident } \\
\text { Investors } \\
\end{array}$} & \multirow{2}{*}{$\begin{array}{l}\text { Non-Resident } \\
\text { Investors }\end{array}$} & \multicolumn{3}{|c|}{ Non-Resident Investors } \\
\hline & & & & $\begin{array}{c}\text { Asian } \\
\text { Investors }\end{array}$ & US Investors & $\begin{array}{l}\text { Others } \\
\text { Investors }\end{array}$ \\
\hline \multirow[t]{4}{*}{ All Investors } & 2,899 & 510 & 2,389 & 379 & 828 & 1,182 \\
\hline & 2,506 & 480 & 2,026 & 270 & 731 & 1,025 \\
\hline & 2,076 & 464 & 1,612 & 243 & 563 & 806 \\
\hline & 1,832 & 319 & 1,715 & 274 & 579 & 862 \\
\hline \multirow[t]{4}{*}{ Individual Investors } & 768 & 483 & 285 & 133 & 92 & 60 \\
\hline & 674 & 455 & 219 & 76 & 88 & 55 \\
\hline & 639 & 439 & 200 & 71 & 77 & 52 \\
\hline & 560 & 318 & 242 & 120 & 71 & 51 \\
\hline \multirow[t]{4}{*}{ Institutional Investors } & 2,131 & 27 & 2,104 & 246 & 736 & 1,122 \\
\hline & 1,832 & 25 & 1,807 & 194 & 643 & 970 \\
\hline & 1,437 & 25 & 1,412 & 172 & 486 & 862 \\
\hline & 1,474 & 1 & 1,473 & 154 & 508 & 811 \\
\hline
\end{tabular}

Note: The investor number refers to the number of unique investor ID codes. The investors in the table include only those who registered at the Korea Securities Supervisory Board (KSSB) before December 31, 1996 and who are portfolio investors. The first row in each cell counts the number of investors who held at least one share of stock in the first section of the Korea Stock Exchange (KSE) any month during the sample period. Subsequent figures are the numbers of investors that hold at least one share of stock on three dates: Jan. 31, 1997, Nov. 29, 1997, and June 30, 1998.

Table 1b: Market Value of the Stock Positions of Foreign Investors

(On Dec. 27, 1996, Nov. 29, 1997, and Jun 30, 1998)

(Unit: Billion Korean wons)

\begin{tabular}{||l|r|r|r|r|r|r||}
\hline & All Investors & \multicolumn{1}{|c|}{$\begin{array}{c}\text { Resident } \\
\text { Investors }\end{array}$} & $\begin{array}{c}\text { Non-Resident } \\
\text { Investors }\end{array}$ & \multicolumn{2}{|c||}{ Non-Resident Investors } \\
& & & & $\begin{array}{c}\text { Asian } \\
\text { Investors }\end{array}$ & $\begin{array}{c}\text { US } \\
\text { Investors }\end{array}$ & $\begin{array}{c}\text { Others } \\
\text { Investors }\end{array}$ \\
\hline All Investors & 11,415 & 109 & 11,305 & 1,324 & 5,593 & 4,388 \\
& 7,056 & 188 & 6868 & 550 & 4,257 & 2,061 \\
& 8,584 & 25 & 8560 & 472 & 5,261 & 2,826 \\
\hline Individual Investors & 49 & 28 & 21 & 6 & 10 & 6 \\
& 29 & 17 & 12 & 4 & 2 & 1 \\
& 31 & 25 & 6 & 3 & & 2 \\
& 11,366 & 81 & 11,284 & 1,319 & 5,583 & 4,383 \\
& 7,026 & 171 & 6856 & 546 & 4,250 & 2,059 \\
& 8,554 & 0.12 & 8554 & 470 & 5,259 & 2,825 \\
\hline
\end{tabular}

Notes: (1) Each cell in the table reports the market values of the stock positions for a given investor group on three dates: Dec. 27, 1996, Nov. 29, 1997, and June 30, 1998. Only those investors who are included in Table 1a are included here.

(2) The market values of all the stocks listed on the first section of the Korean Stock Exchange are 88,853 (Dec. 27, 96), 61,401 (Nov. 29, 97), and 50,256 (Jun 30, 98) billion wons, respectively. 
Table 2. Positive Feedback Trading (Net Purchase)

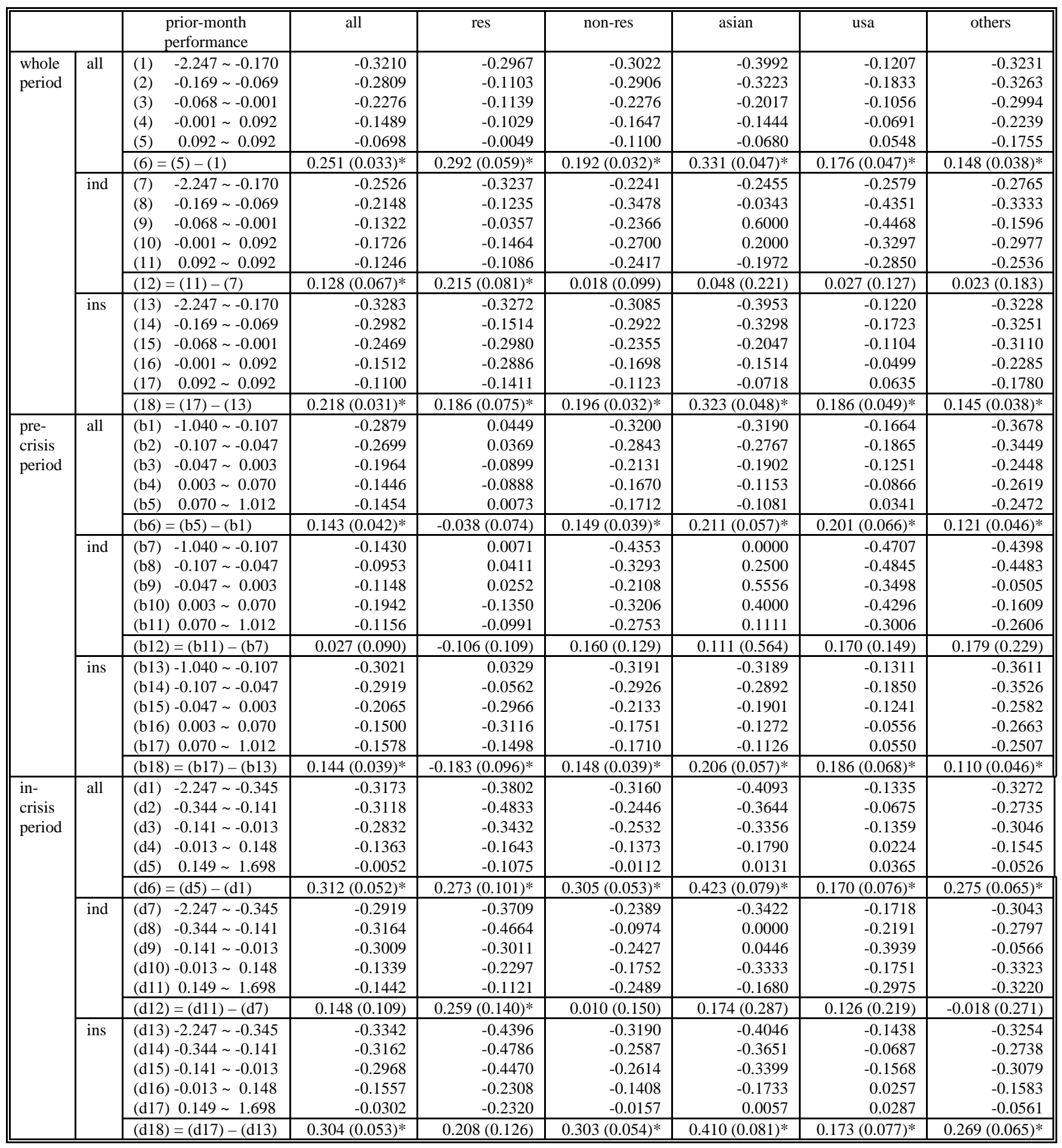

Stock-months are divided into five groups according to prior-month return, defined as return in excess of the KOSPI return mimus the won depreciation against the US dollar. For each group, the mean value of net purchase [=(no. of shares purchased - no. of shares sold) / (no. of shares traded)] is reported. The whole period covers December, 1996-June, 1998. The first half of the sample up to and including October, 1997 is defined as the pre-crisis subperiod. The remaining eight months are the in-crisis sub-period. Within each investor group and sample period, t-test is performed on the buyer's ratio for stocks that are best and worst performers in the previous month. Standard errors are in the parentheses. * indicates significant at the $10 \%$ level. 
Table 3. Positive Feedback Trading (Buyer's Ratio)

\begin{tabular}{|c|c|c|c|c|c|c|c|c|}
\hline & & $\begin{array}{l}\text { prior-month } \\
\text { performance }\end{array}$ & all & res & non-res & asian & usa & others \\
\hline \multirow{18}{*}{$\begin{array}{l}\text { whole } \\
\text { period }\end{array}$} & \multirow[t]{6}{*}{ all } & (1) $-2.247 \sim-0.170$ & 0.3249 & 0.3595 & 0.3344 & 0.2961 & 0.4199 & 0.3392 \\
\hline & & $-0.169 \sim-0.069$ & 0.3642 & 0.4481 & 0.3554 & 0.3433 & 0.4087 & 0.3387 \\
\hline & & $-0.068 \sim-0.001$ & 0.3808 & 0.4588 & 0.3789 & 0.4010 & 0.4411 & 0.3393 \\
\hline & & $-0.001 \sim 0.092$ & 0.4207 & 0.4502 & 0.4159 & 0.4320 & 0.4492 & 0.3912 \\
\hline & & $0.092 \sim 0.092$ & 0.4578 & 0.4893 & 0.4351 & 0.4696 & 0.5255 & 0.3937 \\
\hline & & $(6)=(5)-(1)$ & $0.133(0.015)^{*}$ & $0.130(0.028)^{*}$ & $0.101(0.014)^{*}$ & $0.173(0.022)^{*}$ & $0.106(0.022)^{*}$ & $0.055(0.018)^{*}$ \\
\hline & \multirow[t]{6}{*}{ ind } & (7) $-2.247 \sim-0.170$ & 0.3625 & 0.3361 & 0.3842 & 0.3802 & 0.3780 & 0.3535 \\
\hline & & (8) $-0.169 \sim-0.069$ & 0.3870 & 0.4348 & 0.3243 & 0.4835 & 0.2934 & 0.3333 \\
\hline & & $-0.068 \sim-0.001$ & 0.4371 & 0.4723 & 0.3821 & 0.8000 & 0.2756 & 0.4181 \\
\hline & & (10) $-0.001 \sim 0.092$ & 0.4170 & 0.4282 & 0.3635 & 0.6000 & 0.3441 & 0.3485 \\
\hline & & (11) $0.092 \sim 0.092$ & 0.4419 & 0.4422 & 0.3902 & 0.4315 & 0.3708 & 0.3721 \\
\hline & & $(12)=(11)-(7)$ & $0.079(0.033)^{*}$ & $0.106(0.040)^{*}$ & $0.006(0.048)$ & $0.051(0.110)$ & $0.007(0.062)$ & $0.019(0.090)$ \\
\hline & \multirow[t]{6}{*}{ ins } & (13) $-2.247 \sim-0.170$ & 0.3227 & 0.3388 & 0.3337 & 0.2928 & 0.4212 & 0.3375 \\
\hline & & (14) $-0.169 \sim-0.069$ & 0.3565 & 0.4297 & 0.3560 & 0.3395 & 0.4197 & 0.3386 \\
\hline & & (15) $-0.068 \sim-0.001$ & 0.3697 & 0.3698 & 0.3752 & 0.3964 & 0.4422 & 0.3337 \\
\hline & & (16) $-0.001 \sim 0.092$ & 0.4219 & 0.3670 & 0.4152 & 0.4268 & 0.4612 & 0.3915 \\
\hline & & (17) $0.092 \sim 0.092$ & 0.4392 & 0.4219 & 0.4345 & 0.4673 & 0.5349 & 0.3925 \\
\hline & & $(18)=(17)-(13)$ & $0.117(0.014)^{*}$ & $0.083(0.036)^{*}$ & $0.101(0.015)^{*}$ & $0.175(0.022)^{*}$ & $0.114(0.023)^{*}$ & $0.055(0.018)^{*}$ \\
\hline \multirow{18}{*}{$\begin{array}{l}\text { pre- } \\
\text { crisis } \\
\text { period }\end{array}$} & \multirow[t]{6}{*}{ all } & (b1) $-1.040 \sim-0.107$ & 0.3730 & 0.5237 & 0.3479 & 0.3567 & 0.4055 & 0.3196 \\
\hline & & (b2) $-0.107 \sim-0.047$ & 0.3695 & 0.5169 & 0.3574 & 0.3627 & 0.4145 & 0.3279 \\
\hline & & (b3) $-0.047 \sim 0.003$ & 0.3995 & 0.4896 & 0.3864 & 0.4044 & 0.4325 & 0.3592 \\
\hline & & (b4) $0.003 \sim 0.070$ & 0.4227 & 0.4509 & 0.4174 & 0.4456 & 0.4493 & 0.3767 \\
\hline & & (b5) $0.070 \sim 1.012$ & 0.4385 & 0.5022 & 0.4129 & 0.4608 & 0.5106 & 0.3707 \\
\hline & & $(\mathrm{b} 6)=(\mathrm{b} 5)-(\mathrm{b} 1)$ & $0.066(0.019)^{*}$ & $-0.021(0.035)$ & $0.065(0.018)^{*}$ & $0.104(0.026)^{*}$ & $0.105(0.031)^{*}$ & $0.051(0.021)^{*}$ \\
\hline & \multirow[t]{6}{*}{ ind } & (b7) $-1.040 \sim-0.107$ & 0.4243 & 0.5033 & 0.2947 & 0.5000 & 0.2735 & 0.2734 \\
\hline & & (b8) $-0.107 \sim-0.047$ & 0.4409 & 0.5226 & 0.3207 & 0.6250 & 0.2520 & 0.2759 \\
\hline & & (b9) $-0.047 \sim 0.003$ & 0.4522 & 0.5161 & 0.3881 & 0.7778 & 0.3071 & 0.4775 \\
\hline & & (b10) $0.003 \sim 0.070$ & 0.4017 & 0.4301 & 0.3494 & 0.7000 & 0.3062 & 0.4107 \\
\hline & & (b11) $0.070 \sim 1.012$ & 0.4432 & 0.4455 & 0.3691 & 0.5556 & 0.3693 & 0.3762 \\
\hline & & $(\mathrm{b} 12)=(\mathrm{b} 11)-(\mathrm{b} 7)$ & $0.019(0.044)$ & $-0.058(0.054)$ & $0.074(0.064)$ & $0.056(0.282)$ & $0.096(0.074)$ & $0.103(0.113)$ \\
\hline & \multirow[t]{6}{*}{ ins } & (b13) $-1.040 \sim-0.107$ & 0.3676 & 0.5267 & 0.3516 & 0.3566 & 0.4310 & 0.3218 \\
\hline & & (b14) $-0.107 \sim-0.047$ & 0.3583 & 0.4758 & 0.3544 & 0.3566 & 0.4208 & 0.3237 \\
\hline & & (b15) $-0.047 \sim 0.003$ & 0.3905 & 0.3909 & 0.3865 & 0.4029 & 0.4372 & 0.3540 \\
\hline & & (b16) $0.003 \sim 0.070$ & 0.4249 & 0.3573 & 0.4163 & 0.4390 & 0.4702 & 0.3757 \\
\hline & & (b17) $0.070 \sim 1.012$ & 0.4245 & 0.4251 & 0.4133 & 0.4580 & 0.5253 & 0.3690 \\
\hline & & $(\mathrm{b} 18)=(\mathrm{b} 17)-(\mathrm{b} 13)$ & $0.057(0.017)^{*}$ & $-0.102(0.045)^{*}$ & $0.062(0.018)^{*}$ & $0.102(0.026)^{*}$ & $0.094(0.032)^{*}$ & $0.047(0.022)^{*}$ \\
\hline \multirow{18}{*}{$\begin{array}{l}\text { in- } \\
\text { crisis } \\
\text { period }\end{array}$} & \multirow[t]{6}{*}{ all } & (d1) $-2.247 \sim-0.345$ & 0.3167 & 0.3169 & 0.3189 & 0.2812 & 0.4131 & 0.3370 \\
\hline & & (d2) $-0.344 \sim-0.141$ & 0.3234 & 0.2692 & 0.3684 & 0.3175 & 0.4466 & 0.3577 \\
\hline & & (d3) $-0.141 \sim-0.013$ & 0.3396 & 0.3216 & 0.3554 & 0.3321 & 0.4261 & 0.3539 \\
\hline & & (d4) $-0.013 \sim 0.148$ & 0.4173 & 0.4064 & 0.4204 & 0.4006 & 0.4861 & 0.4081 \\
\hline & & (d5) $0.149 \sim 1.698$ & 0.4760 & 0.4445 & 0.4718 & 0.4954 & 0.5220 & 0.4363 \\
\hline & & $(\mathrm{d} 6)=(\mathrm{d} 5)-(\mathrm{d} 1)$ & $0.159(0.023)^{*}$ & $0.128(0.048)^{*}$ & $0.153(0.024)^{*}$ & $0.214(0.037)^{*}$ & $0.109(0.035)^{*}$ & $0.099(0.030)^{*}$ \\
\hline & \multirow[t]{6}{*}{ ind } & (d7) $-2.247 \sim-0.345$ & 0.3423 & 0.3037 & 0.3541 & 0.3333 & 0.3929 & 0.3478 \\
\hline & & $(\mathrm{d} 8) \quad-0.344 \sim-0.141$ & 0.3250 & 0.2563 & 0.4542 & 0.5000 & 0.4060 & 0.3482 \\
\hline & & (d9) $-0.141 \sim-0.013$ & 0.3515 & 0.3343 & 0.3870 & 0.5232 & 0.3429 & 0.4667 \\
\hline & & $(\mathrm{d} 10)-0.013 \sim 0.148$ & 0.4405 & 0.3924 & 0.4081 & 0.3333 & 0.3986 & 0.3417 \\
\hline & & (d11) $0.149 \sim 1.698$ & 0.4412 & 0.4404 & 0.3937 & 0.4722 & 0.3682 & 0.3205 \\
\hline & & $(\mathrm{d} 12)=(\mathrm{d} 11)-(\mathrm{d} 7)$ & $0.099(0.052)^{*}$ & $0.137(0.069)^{*}$ & $0.040(0.072)$ & $0.139(0.143)$ & $0.025(0.107)$ & $0.027(0.133)$ \\
\hline & \multirow[t]{6}{*}{ ins } & $(\mathrm{d} 13)-2.247 \sim-0.345$ & 0.3121 & 0.2948 & 0.3230 & 0.2796 & 0.4064 & 0.3356 \\
\hline & & (d14) $-0.344 \sim-0.141$ & 0.3222 & 0.2547 & 0.3582 & 0.3067 & 0.4488 & 0.3552 \\
\hline & & (d15) $-0.141 \sim-0.013$ & 0.3335 & 0.2545 & 0.3519 & 0.3251 & 0.4175 & 0.3516 \\
\hline & & $(\mathrm{d} 16)-0.013 \sim 0.148$ & 0.4110 & 0.3673 & 0.4192 & 0.3996 & 0.4875 & 0.4095 \\
\hline & & (d17) $0.149 \sim 1.698$ & 0.4654 & 0.3839 & 0.4703 & 0.4907 & 0.5240 & 0.4351 \\
\hline & & $(\mathrm{d} 18)=(\mathrm{d} 17)-(\mathrm{d} 13)$ & $0.153(0.024)^{*}$ & $0.089(0.060)$ & $0.147(0.025)^{*}$ & $0.211(0.038)^{*}$ & $0.118(0.036)^{*}$ & $0.100(0.030)^{*}$ \\
\hline
\end{tabular}

Stock-months are divided into five groups according to prior-month return, defined as return in excess of the KOSPI return mimus the won depreciation against the US dollar. For each group, the mean value of buyers' ratio [=(no. of buyers) / (no. of traders)] is reported. The whole period covers December, 996-June, 1998. The first half of the sample up to and including October, 1997 is defined as the pre-crisis sub-period. The remaining eight months are the in-crisis sub-period. Within each investor group and sample period, t-test is performed on the buyer's ratio for stocks that are best and worst performers in the previous month. Standard errors are in the parentheses. * indicates significant at the $10 \%$ level. 
Table 4. Ex-Post Rationality of Positive Feedback Trading

\begin{tabular}{|c|c|c|c|c|c|c|c|c|}
\hline \multicolumn{9}{|c|}{ Whole Sample Period } \\
\hline Investment & \multicolumn{4}{|c|}{ Returns of 10 Best \& Worst Performers } & \multicolumn{4}{|c|}{ Returns of 30 Best \& Worst Performers } \\
\hline & Best & Worst & Difference & s.e. & Best & Worst & Difference & s.e. \\
\hline-1 & 0.536 & -0.589 & $1.125^{* *}$ & 0.044 & 0.368 & -0.440 & $0.809^{* *}$ & 0.019 \\
\hline 1 & -0.080 & -0.002 & $-0.078 * *$ & 0.038 & -0.083 & -0.007 & $-0.077 * *$ & 0.019 \\
\hline 2 & -0.161 & -0.077 & -0.084 & 0.057 & -0.152 & -0.083 & $-0.069 * *$ & 0.028 \\
\hline 3 & -0.256 & -0.142 & $-0.114 *$ & 0.064 & -0.228 & -0.108 & $-0.120 * *$ & 0.033 \\
\hline 4 & -0.279 & -0.201 & -0.078 & 0.070 & -0.295 & -0.169 & $-0.126 * *$ & 0.037 \\
\hline 5 & -0.342 & -0.285 & -0.057 & 0.084 & -0.332 & -0.239 & $-0.094 * *$ & 0.041 \\
\hline 6 & -0.460 & -0.362 & -0.098 & 0.087 & -0.381 & -0.340 & -0.041 & 0.045 \\
\hline \multicolumn{9}{|c|}{ Pre-Crisis Period } \\
\hline $\begin{array}{c}\text { Investment } \\
\text { Horizon }\end{array}$ & \multicolumn{4}{|c|}{ Returns of 10 Best \& Worst Performers } & \multicolumn{4}{|c|}{ Returns of 30 Best $\&$ Worst Performers } \\
\hline & Best & Worst & Difference & s.e. & Best & Worst & Difference & s.e. \\
\hline-1 & 0.523 & -0.370 & $0.893^{* *}$ & 0.022 & 0.368 & -0.279 & $0.646^{* *}$ & 0.011 \\
\hline 1 & -0.067 & -0.036 & -0.031 & 0.040 & -0.064 & -0.010 & $-0.054 * *$ & 0.020 \\
\hline 2 & -0.148 & -0.192 & 0.044 & 0.072 & -0.145 & -0.155 & 0.010 & 0.037 \\
\hline 3 & -0.288 & -0.273 & -0.015 & 0.084 & -0.257 & -0.196 & -0.061 & 0.044 \\
\hline 4 & -0.367 & -0.386 & 0.019 & 0.096 & -0.373 & -0.315 & -0.057 & 0.052 \\
\hline 5 & -0.467 & -0.484 & 0.017 & 0.116 & -0.446 & -0.384 & -0.063 & 0.056 \\
\hline 6 & -0.555 & -0.548 & -0.007 & 0.111 & -0.503 & -0.493 & -0.010 & 0.057 \\
\hline \multicolumn{9}{|c|}{ In-Crisis Period } \\
\hline Investment & \multicolumn{4}{|c|}{ Returns of 10 Best \& Worst Performers } & \multicolumn{4}{|c|}{ Returns of 30 Best $\&$ Worst Performers } \\
\hline & Best & Worst & Difference & s.e. & Best & Worst & Difference & s.e. \\
\hline-1 & 0.597 & -0.615 & $1.212^{* *}$ & 0.045 & 0.401 & -0.446 & $0.847^{* *}$ & 0.018 \\
\hline 1 & -0.095 & -0.001 & $-0.094 * *$ & 0.035 & -0.099 & -0.008 & $-0.090 * *$ & 0.018 \\
\hline 2 & -0.173 & -0.069 & $-0.105^{*}$ & 0.054 & -0.164 & -0.072 & $-0.092 * *$ & 0.027 \\
\hline 3 & -0.254 & -0.143 & $-0.111^{*}$ & 0.061 & -0.227 & -0.105 & $-0.121 * *$ & 0.031 \\
\hline 4 & -0.279 & -0.201 & -0.078 & 0.070 & -0.295 & -0.169 & $-0.126^{* *}$ & 0.037 \\
\hline 5 & -0.342 & -0.285 & -0.057 & 0.084 & -0.332 & -0.239 & $-0.094 * *$ & 0.041 \\
\hline 6 & -0.460 & -0.362 & -0.098 & 0.087 & -0.381 & -0.340 & -0.041 & 0.045 \\
\hline
\end{tabular}

We form protfolios of best and worst performers based on the previous month excess returns (reported in the rows labeled as "horizon -1"), and then track their relative performance in the subsequent six months (reported in rows labeled as "horizons 1-6"). The return (for a given stock) is defined as $\left(\ln _{t}-\ln P_{t-1}\right)-\left(\ln K_{t}-\ln K_{t-1}\right)-\left(S_{t}-S_{t+1}\right)$, where $P_{t}$ is stock price, $K_{t}$ is KOSPI market index, and $\mathrm{S}_{\mathrm{t}}$ is spot exchange rate (won/US dollar). Since price data is available only up to October 1998, the computations are constrained accordingly. $* *$ and $*$ denote significant at the $5 \%$ and $10 \%$ levels, respectively. 
Table 5. Herding

\begin{tabular}{|c|c|c|c|c|c|}
\hline & & $\begin{array}{c}\text { (1) } \\
\text { All Investors }\end{array}$ & $\begin{array}{c}(2) \\
\text { Non-Resident } \\
\text { Investors }\end{array}$ & $\begin{array}{c}\text { (3) } \\
\text { Resident } \\
\text { Investors }\end{array}$ & $(4)=(2)-(3)$ \\
\hline \multirow[t]{4}{*}{$\begin{array}{l}\text { Whole } \\
\text { Period }\end{array}$} & (1) All Investors & $\begin{array}{l}0.0562 * * \\
(0.0024)\end{array}$ & $\begin{array}{l}0.0623 * * \\
(0.0026)\end{array}$ & $\begin{array}{l}0.0186 * * \\
(0.0052)\end{array}$ & $\begin{array}{l}0.0437 * * \\
(0.0058)\end{array}$ \\
\hline & (2) Individual Investors & $\begin{array}{l}0.1091 * * \\
(0.0074)\end{array}$ & $\begin{array}{l}0.1452 * * \\
(0.0100)\end{array}$ & $\begin{array}{l}0.0949 * * \\
(0.0107)\end{array}$ & $\begin{array}{l}0.0502 * * \\
(0.0146)\end{array}$ \\
\hline & (3) Institutional Investors & $\begin{array}{l}0.0548 * * \\
(0.0025)\end{array}$ & $\begin{array}{l}0.0599 * * \\
(0.0026)\end{array}$ & $\begin{array}{l}0.0070 \\
(0.0061)\end{array}$ & $\begin{array}{l}0.0529 * * \\
(0.0072)\end{array}$ \\
\hline & $(4)=(2)-(3)$ & $\begin{array}{l}0.0544 * * \\
(0.0070)\end{array}$ & $\begin{array}{l}0.0853 * * \\
(0.0095)\end{array}$ & $\begin{array}{l}0.0878 * * \\
(0.0114)\end{array}$ & \\
\hline \multirow[t]{4}{*}{$\begin{array}{r}\text { Pre-Crisis } \\
\text { Period }\end{array}$} & (5) All Investors & $\begin{array}{l}0.0497 * * \\
(0.0031)\end{array}$ & $\begin{array}{l}0.0613 * * \\
(0.0033) \\
\end{array}$ & $\begin{array}{l}0.0150 * * \\
(0.0068) \\
\end{array}$ & $\begin{array}{l}0.0463 * * \\
(0.0075) \\
\end{array}$ \\
\hline & (6) Individual Investors & $\begin{array}{l}0.1050 * * \\
(0.0108) \\
\end{array}$ & $\begin{array}{l}0.1515 * * \\
(0.0144) \\
\end{array}$ & $\begin{array}{l}0.1050 * * \\
(0.0148) \\
\end{array}$ & $\begin{array}{l}0.0464 * * \\
(0.0208) \\
\end{array}$ \\
\hline & (7) Institutional Investors & $\begin{array}{l}0.0503 * * \\
(0.0031)\end{array}$ & $\begin{array}{l}0.0597 * * \\
(0.0033)\end{array}$ & $\begin{array}{l}0.0056 \\
(0.0094)\end{array}$ & $\begin{array}{l}0.0541 * * \\
(0.0101)\end{array}$ \\
\hline & $(8)=(6)-(7)$ & $\begin{array}{l}0.0547 * * \\
(0.0095)\end{array}$ & $\begin{array}{l}0.0917 * * \\
(0.0135)\end{array}$ & $\begin{array}{l}0.0995 * * \\
(0.0167)\end{array}$ & \\
\hline \multirow[t]{4}{*}{$\begin{array}{r}\text { In-Crisis } \\
\text { Period }\end{array}$} & (9) All Investors & $\begin{array}{l}0.0667 * * \\
(0.0040)\end{array}$ & $\begin{array}{l}0.0639 * * \\
(0.0042)\end{array}$ & $\begin{array}{l}0.0240 * * \\
(0.0082)\end{array}$ & $\begin{array}{l}0.0399 * * \\
(0.0092)\end{array}$ \\
\hline & (10) Individual Investors & $\begin{array}{l}0.1137 * * \\
(0.0099)\end{array}$ & $\begin{array}{l}0.1391 * * \\
(0.0138)\end{array}$ & $\begin{array}{l}0.0832 * * \\
(0.0154)\end{array}$ & $\begin{array}{l}0.0559 * * \\
(0.0206)\end{array}$ \\
\hline & (11) Institutional Investors & $\begin{array}{l}0.0620 * * \\
(0.0041)\end{array}$ & $\begin{array}{l}0.0602 * * \\
(0.0042)\end{array}$ & $\begin{array}{l}0.0086 \\
(0.0078) \\
\end{array}$ & $\begin{array}{l}0.0516 * * \\
(0.0103) \\
\end{array}$ \\
\hline & $(12)=(10)-(11)$ & $\begin{array}{l}0.0517 * * \\
(0.0103)\end{array}$ & $\begin{array}{l}0.0789 * * \\
(0.0134)\end{array}$ & $\begin{array}{l}0.0746 * * \\
(0.0155)\end{array}$ & \\
\hline \multirow[t]{3}{*}{$\begin{array}{c}\text { Tests of } \\
\text { Differences }\end{array}$} & $(13)=(9)-(5)$ & $\begin{array}{l}0.0170 * * \\
(0.0050)\end{array}$ & $\begin{array}{l}0.0026 \\
(0.0053)\end{array}$ & $\begin{array}{l}0.0090 \\
(0.0107)\end{array}$ & \\
\hline & $(14)=(10)-(6)$ & $\begin{array}{l}0.0087 \\
(0.0148)\end{array}$ & $\begin{array}{l}-0.0124 \\
(0.0200)\end{array}$ & $\begin{array}{l}-0.0219 \\
(0.0214) \\
\end{array}$ & \\
\hline & $(15)=(11)-(7)$ & $\begin{array}{l}0.0117 * * \\
(0.0051)\end{array}$ & $\begin{array}{l}0.0005 \\
(0.0054)\end{array}$ & $\begin{array}{l}0.0030 \\
(0.0123)\end{array}$ & \\
\hline
\end{tabular}

Note: Standard errors are in the parentheses. $* *$ and $*$ denote significant at the $5 \%$ and $10 \%$ levels, respectively. 
Table 6. Ex-Post Rationality on Herding (Net Purchase)

\begin{tabular}{|c|c|c|c|c|c|c|c|c|c|c|c|}
\hline & & \multicolumn{10}{|c|}{ One Month Investment Horizon } \\
\hline & & \multicolumn{2}{|c|}{$\begin{array}{c}\text { All } \\
\text { Investors }\end{array}$} & \multicolumn{2}{|c|}{ Resident Investors } & \multicolumn{2}{|c|}{$\begin{array}{c}\text { Non-Resident } \\
\text { Investors }\end{array}$} & \multicolumn{4}{|c|}{ Non-Resident Investors } \\
\hline & & & & & & & & Asian & nvestors & US & vestors \\
\hline & & $\beta_{0}$ & $\beta_{I}$ & $\beta_{0}$ & $\beta_{1}$ & $\beta_{0}$ & $\beta_{1}$ & $\beta_{0}$ & $\beta_{I}$ & $\beta_{0}$ & $\beta_{I}$ \\
\hline \multirow[t]{4}{*}{$\begin{array}{l}\text { Whole } \\
\text { period }\end{array}$} & $\begin{array}{c}\text { All } \\
\text { Investors }\end{array}$ & $\begin{array}{l}0.005 \\
(0.005)\end{array}$ & $\begin{array}{l}0.007 \\
(0.026)\end{array}$ & $\begin{array}{l}0.007 \\
(0.009)\end{array}$ & $\begin{array}{l}0.027 \\
(0.042)\end{array}$ & $\begin{array}{l}0.006 \\
(0.006)\end{array}$ & $\begin{array}{l}-0.005 \\
(0.027)\end{array}$ & $\begin{array}{l}0.007 \\
(0.007)\end{array}$ & $\begin{array}{l}-0.010 \\
(0.036)\end{array}$ & $\begin{array}{l}0.000 \\
(0.008)\end{array}$ & $\begin{array}{l}0.017 \\
(0.037)\end{array}$ \\
\hline & Individual & 0.014 & 0.001 & -0.012 & 0.018 & 0.018 & -0.013 & 0.222 & -0.847 & 0.040 & -0.111 \\
\hline & Investors & $(0.015)$ & $(0.063)$ & $(0.022)$ & $(0.088)$ & $(0.031)$ & $(0.123)$ & $(0.214)$ & $(0.907)$ & $(0.050)$ & $(0.190)$ \\
\hline & $\begin{array}{l}\text { Institution. } \\
\text { Investors }\end{array}$ & $\begin{array}{l}0.002 \\
(0.006)\end{array}$ & $\begin{array}{l}0.026 \\
(0.027)\end{array}$ & $\begin{array}{l}0.009 \\
(0.011)\end{array}$ & $\begin{array}{l}0.018 \\
(0.059)\end{array}$ & $\begin{array}{l}0.002 \\
(0.006)\end{array}$ & $\begin{array}{l}0.014 \\
(0.028)\end{array}$ & $\begin{array}{l}0.005 \\
(0.007)\end{array}$ & $\begin{array}{l}0.006 \\
(0.035)\end{array}$ & $\begin{array}{l}-0.002 \\
(0.009)\end{array}$ & $\begin{array}{l}0.036 \\
(0.039)\end{array}$ \\
\hline \multirow[t]{3}{*}{$\begin{array}{r}\text { Pre-Crisis } \\
\text { period }\end{array}$} & All & $\begin{array}{l}-0.002 \\
(0.005)\end{array}$ & $\begin{array}{l}0.034 \\
(0.024)\end{array}$ & $\begin{array}{l}0.004 \\
(0.007)\end{array}$ & $\begin{array}{l}0.062 * * \\
(0.036)\end{array}$ & $\begin{array}{l}-0.005 \\
(0.006)\end{array}$ & $\begin{array}{l}0.042 \\
(0.026)\end{array}$ & $\begin{array}{l}-0.008 \\
(0.006)\end{array}$ & $\begin{array}{l}0.022 \\
(0.028)\end{array}$ & $\begin{array}{l}0.001 \\
(0.008)\end{array}$ & $\begin{array}{l}0.018 \\
(0.033)\end{array}$ \\
\hline & Individual & $\begin{array}{l}0.013 \\
(0.011)\end{array}$ & $\begin{array}{l}-0.017 \\
(0.045)\end{array}$ & $\begin{array}{l}0.002 \\
(0.018)\end{array}$ & $\begin{array}{l}0.036 \\
(0.073)\end{array}$ & $\begin{array}{l}0.023 \\
(0.022)\end{array}$ & $\begin{array}{l}-0.029 \\
(0.085)\end{array}$ & $\begin{array}{l}-0.475 \\
(0.805)\end{array}$ & $\begin{array}{l}1.653 \\
(3.372)\end{array}$ & $\begin{array}{l}0.019 \\
(0.036)\end{array}$ & $\begin{array}{l}-0.005 \\
(0.139)\end{array}$ \\
\hline & Institution & $\begin{array}{l}-0.004 \\
(0.005)\end{array}$ & $\begin{array}{l}0.051^{* *} \\
(0.025)\end{array}$ & $\begin{array}{l}0.007 \\
(0.010)\end{array}$ & $\begin{array}{l}0.066 \\
(0.053)\end{array}$ & $\begin{array}{l}-0.007 \\
(0.006)\end{array}$ & $\begin{array}{l}0.052^{* *} \\
(0.026)\end{array}$ & $\begin{array}{l}-0.008 \\
(0.006)\end{array}$ & $\begin{array}{l}0.022 \\
(0.029)\end{array}$ & $\begin{array}{l}-0.001 \\
(0.008)\end{array}$ & $\begin{array}{l}0.026 \\
(0.036)\end{array}$ \\
\hline \multirow{4}{*}{$\begin{array}{r}\text { In-Crisis } \\
\text { period }\end{array}$} & All & $\begin{array}{l}0.015 \\
(0.012)\end{array}$ & $\begin{array}{l}-0.045 \\
(0.057)\end{array}$ & $\begin{array}{l}0.015 \\
(0.021)\end{array}$ & $\begin{array}{l}-0.046 \\
(0.098)\end{array}$ & $\begin{array}{l}0.021 * \\
(0012)\end{array}$ & $\begin{array}{l}-0.090 \\
(0.058)\end{array}$ & $\begin{array}{l}0.033^{*} \\
(0.020)\end{array}$ & $\begin{array}{l}-0.112 \\
(0.097)\end{array}$ & 0.001 & 0.004 \\
\hline & Individual & -0.002 & 0.097 & -0.046 & -0.005 & 0.001 & 0.055 & 0.238 & -0.827 & 0.078 & -0.209 \\
\hline & & $(0.032)$ & $(0.136)$ & $(0.050)$ & $(0.204)$ & $(0.057)$ & $(0.235)$ & $(0.241)$ & $(1.025)$ & $(0.128)$ & $(0.470)$ \\
\hline & Institution & $\begin{array}{l}0.011 \\
(0.012)\end{array}$ & $\begin{array}{l}-0.022 \\
(0.059)\end{array}$ & $\begin{array}{l}0.009 \\
(0.024)\end{array}$ & $\begin{array}{l}-0.027 \\
(0.121)\end{array}$ & $\begin{array}{l}0.013 \\
(0.013)\end{array}$ & $\begin{array}{l}-0.054 \\
(0.061)\end{array}$ & $\begin{array}{l}0.029 \\
(0.020)\end{array}$ & $\begin{array}{l}-0.061 \\
(0.102)\end{array}$ & $\begin{array}{l}-0.001 \\
(0.016)\end{array}$ & $\begin{array}{l}0.041 \\
(0.075)\end{array}$ \\
\hline & & \multicolumn{10}{|c|}{ Three Month Investment Horizon } \\
\hline & & \multicolumn{2}{|c|}{$\begin{array}{c}\text { All } \\
\text { Investors }\end{array}$} & \multicolumn{2}{|c|}{ Resident Investors } & \multicolumn{2}{|c|}{$\begin{array}{l}\text { Non-Resident } \\
\text { Investors }\end{array}$} & \multicolumn{4}{|c|}{ Non-Resident Investors } \\
\hline & & & & & & & \multicolumn{2}{|c|}{ Asian Investors } & \multicolumn{2}{|c|}{ US Investors } \\
\hline & & $\beta_{0}$ & $\beta_{1}$ & $\beta_{0}$ & $\beta_{1}$ & $\beta_{0}$ & $\beta_{1}$ & $\beta_{0}$ & $\beta_{1}$ & $\beta_{0}$ & $\beta_{1}$ \\
\hline \multirow[t]{4}{*}{ Whole } & All & $\begin{array}{l}-0.017 * * \\
(0.009)\end{array}$ & $\begin{array}{l}0.065 \\
(0.041)\end{array}$ & $\begin{array}{l}0.002 \\
(0.012)\end{array}$ & $\begin{array}{l}0.109^{*} \\
(0.061)\end{array}$ & $\begin{array}{l}-0.011 \\
(0.010)\end{array}$ & $\begin{array}{l}0.015 \\
(0.044)\end{array}$ & $\begin{array}{l}-0.022 * * \\
(0.011)\end{array}$ & $\begin{array}{l}1 \\
0.044 \\
(0.053)\end{array}$ & $\begin{array}{l}-0.003 \\
(0.013)\end{array}$ & $\begin{array}{l}0.057 \\
(0.056)\end{array}$ \\
\hline & Individual & 0.004 & 0.101 & 0.003 & 0.027 & -0.005 & 0.230 & $-1.169 * *$ & 4.742 & 0.032 & 0.226 \\
\hline & & $(0.022)$ & (0.089) & (0.029) & (0.119) & (0.044) & $(0.172)$ & $(0.422)$ & (1.759) & $(0.068)$ & $(0.253)$ \\
\hline & Institution & $\begin{array}{l}-0.018 * * \\
(0.009)\end{array}$ & $\begin{array}{l}0.064 \\
(0.043)\end{array}$ & $\begin{array}{l}-0.002 \\
(0.016)\end{array}$ & $\begin{array}{l}0.074 \\
(0.086)\end{array}$ & $\begin{array}{l}-0.013 \\
(0.010)\end{array}$ & $\begin{array}{l}0.015 \\
(0.044)\end{array}$ & $\begin{array}{l}-0.023 * * \\
(0.011)\end{array}$ & $\begin{array}{l}0.018 \\
(0.053)\end{array}$ & $\begin{array}{l}-0.003 \\
(0.014)\end{array}$ & $\begin{array}{l}0.056 \\
(0.060)\end{array}$ \\
\hline \multirow[t]{3}{*}{$\begin{array}{r}\text { Pre-Crisis } \\
\text { period }\end{array}$} & All & $\begin{array}{l}-0.017 * * \\
(0.009)\end{array}$ & $\begin{array}{l}0.053 \\
(0.042)\end{array}$ & $\begin{array}{l}0.007 \\
(0.013)\end{array}$ & $\begin{array}{l}0.084 \\
(0.063)\end{array}$ & $\begin{array}{l}-0.013 \\
(0.010)\end{array}$ & $\begin{array}{l}0.028 \\
(0.045)\end{array}$ & $\begin{array}{l}-0.033 * * \\
(0.010)\end{array}$ & $\begin{array}{l}0.048 \\
(0.049)\end{array}$ & $\begin{array}{l}-0.006 \\
(0.013)\end{array}$ & $\begin{array}{l}0.062 \\
(0.056)\end{array}$ \\
\hline & Individual & $\begin{array}{l}0.011 \\
(0.022)\end{array}$ & 0.114 & 0.007 & 0.131 & -0.014 & 0.272 & -0.775 & 3.054 & 0.022 & 0.170 \\
\hline & Institution & $\begin{array}{l}-0.017 * * \\
(0.009)\end{array}$ & $\begin{array}{l}0.047 \\
(0.044)\end{array}$ & $\begin{array}{l}0.002 \\
(0.017)\end{array}$ & $\begin{array}{l}0.126 \\
(0.093)\end{array}$ & $\begin{array}{l}-0.014 \\
(0.010)\end{array}$ & $\begin{array}{l}0.024 \\
(0.045)\end{array}$ & $\begin{array}{l}-0.033 * * \\
(0.010)\end{array}$ & $\begin{array}{l}0.030 \\
(0.049)\end{array}$ & $\begin{array}{l}-0.004 \\
(0.014)\end{array}$ & $\begin{array}{l}0.040 \\
(0.061)\end{array}$ \\
\hline \multirow{6}{*}{$\begin{array}{r}\text { In-Crisis } \\
\text { period }\end{array}$} & All & -0.019 & 0.116 & -0.007 & 0.201 & -0.008 & 0.005 & 0.014 & 0.001 & 0.005 & 0.062 \\
\hline & & $(0.021)$ & (0.099) & (0.028) & (0.131) & $(0.022)$ & (0.103) & $(0.031)$ & (0.154) & $(0.029)$ & $(0.130)$ \\
\hline & Individual & -0.026 & 0.304 & -0.005 & -0.127 & -0.001 & 0.278 & $-1.347 * *$ & $5.614^{* *}$ & 0.090 & 0.398 \\
\hline & & $(0.046)$ & $(0.197)$ & $(0.061)$ & $(0.254)$ & $(0.081)$ & $(0.336)$ & $(0.484)$ & (2.050) & $(0.151)$ & $(0.520)$ \\
\hline & Institution. & -0.024 & 0.124 & -0.033 & 0.048 & -0.013 & 0.013 & 0.010 & -0.032 & 0.003 & 0.107 \\
\hline & & $(0.021)$ & $(0.101)$ & $(0.031)$ & $(0.158)$ & $(0.022)$ & $(0.105)$ & $(0.032)$ & $(0.160)$ & $(0.028)$ & $(0.131)$ \\
\hline
\end{tabular}

Note:

$R_{j t+1}=\alpha+\alpha_{k}+\alpha_{t}+\left(\beta_{0}+\beta_{1} H_{j t}\right) N P_{j t}+\varepsilon_{j t}$

where $R_{j t+1}$, Return from t to $t+1$ for stock $j ; \alpha_{t}$, Month dummy; $\alpha_{k}$, Industry dummy; $H_{j t}$, Herding index at time $t$ for stock $j ; N P_{j t}$, Scale adjusted net purchase at time $t$ for stock $j$. 
Table 7. Stock Characteristics and Herding

\begin{tabular}{|c|c|c|c|c|}
\hline \multirow[t]{3}{*}{ Independent Variables } & \multicolumn{4}{|c|}{ Dependent Variable: Herding Indices } \\
\hline & \multicolumn{2}{|c|}{ Residents } & \multicolumn{2}{|c|}{ Non-residents } \\
\hline & Individual & Institutional & Individual & Institutional \\
\hline Constant & $\begin{array}{l}0.0910 * * \\
(0.0205)\end{array}$ & $\begin{array}{l}0.0279 * * \\
(0.0142)\end{array}$ & $\begin{array}{l}0.1613 * * \\
(0.0188)\end{array}$ & $\begin{array}{l}0.0593 * * \\
(0.0043)\end{array}$ \\
\hline WSJ-19 Dummy & $\begin{array}{l}-0.0281 \\
(0.0418)\end{array}$ & $\begin{array}{l}0.0176 \\
(0.0261)\end{array}$ & $\begin{array}{l}0.0399 \\
(0.0357)\end{array}$ & $\begin{array}{l}0.0567 * * \\
(0.0157)\end{array}$ \\
\hline Chaebol-5 Dummy & $\begin{array}{l}0.0307 \\
(0.0279)\end{array}$ & $\begin{array}{l}-0.0351 \\
(0.0201)\end{array}$ & $\begin{array}{l}0.0186 \\
(0.0251)\end{array}$ & $\begin{array}{l}-0.0072 \\
(0.0079)\end{array}$ \\
\hline Crisis Dummy & $\begin{array}{l}-0.0246 \\
(0.0239)\end{array}$ & $\begin{array}{l}0.0119 \\
(0.0194)\end{array}$ & $\begin{array}{l}-0.0009 \\
(0.0224)\end{array}$ & $\begin{array}{l}-0.0049 \\
(0.0057)\end{array}$ \\
\hline $\begin{array}{l}\text { Prior-month Turnover (no. of shares traded } \\
\text { divided by no. of shares outstanding) }\end{array}$ & $\begin{array}{l}0.0185 \\
(0.0468)\end{array}$ & $\begin{array}{l}-0.0872 \\
(0.0475)\end{array}$ & $\begin{array}{l}-0.0321 \\
(0.0380)\end{array}$ & $\begin{array}{l}-0.0101 \\
(0.0076)\end{array}$ \\
\hline $\begin{array}{l}\text { Prior-month Stock Market Capitalization } \\
\text { (price } \times \text { no. of shares outstanding) }\end{array}$ & $\begin{array}{l}-3.35 \mathrm{E}-16 \\
(9.11 \mathrm{E}-15)\end{array}$ & $\begin{array}{l}-5.43 \mathrm{E}-15 \\
(4.74 \mathrm{E}-15)\end{array}$ & $\begin{array}{l}-1.40 \mathrm{E}-14 \\
(1.01 \mathrm{E}-14)\end{array}$ & $\begin{array}{l}-4.37 \mathrm{E}-15 \\
(3.31 \mathrm{E}-15)\end{array}$ \\
\hline $\begin{array}{l}\text { Prior-month Absolute Return-deviation } \\
\text { from KOSPI Return }\end{array}$ & $\begin{array}{l}-0.0009 \\
(0.0369)\end{array}$ & $\begin{array}{l}0.0323 \\
(0.0621)\end{array}$ & $\begin{array}{l}-0.0914 \\
(0.0717)\end{array}$ & $\begin{array}{l}0.0315 * \\
(0.0166)\end{array}$ \\
\hline No. of Observations & 314 & 430 & 331 & 3,805 \\
\hline Adjusted R Squares & -0.0104 & 0.0022 & 0.0031 & 0.0032 \\
\hline
\end{tabular}

Notes: WSJ-19 is a dummy for the 19 stocks reported daily in the World Stock Markets section of The Wall Street Journal. They are Dacom, Daewoo Heavy Industry, Hyundai Engineering and Construction, Hyundai Electronics Industrial, KEPCO, Kia Motor, Koomin Bank, LG Chemical, LG Electronics, LG Information and Communication, LG Semicon, POSCO, Shinhan Bank, SK Telecom, Samsung Display Devices, Samsung Electronics, Ssangyong Oil Refinery, and Yukong. Chaebol-5 is a dummy for the 62 stocks in the sample affiliated with the five largest Chaebols (Hyundai, Samsung, LG, Daewoo, and Sunkyong). C Crisis is a dummy for the sample period, November, 1997-June, 1998. Standard errors are in parentheses. 
Table 8. Illustrative News (November, 1997)

\begin{tabular}{|c|c|c|c|}
\hline Date & Headlines or Lead Sentences & Source & Label \\
\hline 3-Nov & South Korea Economy Feels The Pressure --- Government's Heavy Hand Can't ... & WSJ & $\mathrm{B}$ \\
\hline 4-Nov & All the fretting about south Asia has risked disguising a larger problem: South Korea & FT & $\mathrm{B}$ \\
\hline 5-Nov & Wobbly Banks Threaten to Drag Down Korea & WSJ & $\mathrm{B}$ \\
\hline $10-\mathrm{Nov}$ & South Korea's Markets Grow Weaker --- Debt Falls to Junk Levels As Stocks ... & WSJ & B \\
\hline $10-$ Nov & S Korea candidates skirt round realities & FT & $\mathrm{B}$ \\
\hline $10-\mathrm{Nov}$ & Troubled Economy Stirs Fears in South Korea & NYT & $\mathrm{B}$ \\
\hline 12-Nov & Asia's Chain Reaction & WSJ & $\mathrm{B}$ \\
\hline 12-Nov & Yen slides as officials keep silent & FT & $\mathrm{B}$ \\
\hline 12-Nov & Korean currency slide shakes economy & FT & B \\
\hline 13-Nov & Fed Leaves Interest Rates Unchanged (Fed was to raise interest rate) & WP & $\mathrm{G}$ \\
\hline 18-Nov & Korea's Won Slides as Bureaucrats Feud --- Protests by Bank Regulators ... & WSJ & B \\
\hline 19-Nov & South Korea's Currency Crisis Deepens And Two Top Officials Suddenly Quit & WSJ & $\mathrm{B}$ \\
\hline 19-Nov & Symptoms Worsening For S. Korean Economy; Currency Drop, Talk of Bailout... & WP & $\mathrm{B}$ \\
\hline 20-Nov & Korea Moves to Tackle Economic Woes & WSJ & G \\
\hline $20-\mathrm{Nov}$ & Korea's Troubles Worsen As Pressure for Aid Grows & NYT & $\mathrm{B}$ \\
\hline 21-Nov & U.S. and IMF Prepare a Rescue for South Korea --- Seoul Dithers as the Won ... & WSJ & G \\
\hline 21-Nov & Japan aid for Seoul 'to come after IMF deal' (Japan turned down aid-offer before IMF) & FT & $\mathrm{B}$ \\
\hline 21-Nov & S Korea admits credit cuts (Japanese banks refusing to roll-over) & FT & $\mathrm{B}$ \\
\hline 22-Nov & S. Korea Rescue May Be Risky Course & WP & $\mathrm{B}$ \\
\hline 24-Nov & Korea Faces Painful Economic Restructuring --- IMF Terms May Spell ... & WSJ & $\mathrm{B}$ \\
\hline 24-Nov & Seoul under pressure on 'shameful' IMF deal (domestic resistance) & FT & $\mathrm{B}$ \\
\hline $25-\mathrm{Nov}$ & APEC set to back Asian stability plan & FT & G \\
\hline $25-\mathrm{Nov}$ & Japan's Folly Drags Asia Down & WSJ & $\mathrm{B}$ \\
\hline $25-\mathrm{Nov}$ & Koreans Bail Out of Stocks on Austerity Fears --- Investors Worry IMF Plan ... & WSJ & $\mathrm{B}$ \\
\hline $25-\mathrm{Nov}$ & For Korean Bank, 'Worst Is Almost Ended' & NYT & $\mathrm{G}$ \\
\hline $27-\mathrm{Nov}$ & Asian Markets: Korea to Boost Its Funds In Effort to Lower Rates (monetary expansion) & WSJ & $\mathrm{G}$ \\
\hline 27-Nov & Seoul warned on union anger & FT & $\mathrm{B}$ \\
\hline 28-Nov & Bond reform fails to excite & FT & $\mathrm{B}$ \\
\hline $28-\mathrm{Nov}$ & S. Korean Official Says \$20 Billion Not Enough & WP & $\mathrm{B}$ \\
\hline 29-Nov & A wounded tiger reluctant to change its stripes & FT & B \\
\hline
\end{tabular}

This is a subset of the news reported as an illustration. Using Lexis-Nexis and Dow-Jones Interactive, we search for news about the Korean economy in five daily newspapers: Wall Street Journal (WSJ), Financial Times (FT), New York Times (NYT), Washington Post (WP), and Korean Herald (KH). The news are then filtered according to a rule explained in the text. 
Table 9. Differences in Net Purchase and News

(resident vs. non-resident US investors)

\begin{tabular}{|c|c|c|c|c|c|c|c|c|c|c|c|}
\hline \multirow[t]{3}{*}{ Month } & \multicolumn{3}{|c|}{ Scale-Adjusted Net Purchase } & \multicolumn{8}{|c|}{ News } \\
\hline & & & & \multicolumn{2}{|c|}{ West-4 } & \multicolumn{2}{|c|}{$\mathrm{KH}$} & \multicolumn{4}{|c|}{ Differences } \\
\hline & $\begin{array}{l}\text { Non-res } \\
\text { US Invt. }\end{array}$ & $\begin{array}{l}\text { Res. } \\
\text { Invt. }\end{array}$ & $\begin{array}{c}(3) \\
= \\
(2)-(1) \\
\text { Diff }\end{array}$ & (4) & (5) & (6) & (7) & $\begin{array}{c}(8) \\
= \\
(4)-(5)\end{array}$ & $\begin{array}{c}(9) \\
= \\
(6)-(7)\end{array}$ & $\begin{array}{c}(10) \\
= \\
(9)-(8)\end{array}$ & $(11)^{\mathrm{a}}$ \\
\hline Jan 97 & 0.1954 & -0.1088 & -0.3042 & 3 & 6 & 1 & 6 & -3 & -5 & -2 & -0.125 \\
\hline Feb 97 & 0.2178 & -0.1227 & -0.3406 & 0 & 6 & 3 & 7 & -6 & -4 & 2 & 0.125 \\
\hline Mar 97 & -0.1072 & -0.0737 & 0.0336 & 2 & 4 & 4 & 11 & -2 & -7 & -5 & -0.238 \\
\hline Apr 97 & -0.1194 & 0.0825 & 0.2019 & 0 & 5 & 5 & 6 & -5 & -1 & 4 & 0.250 \\
\hline May 97 & -0.0401 & 0.5722 & 0.6122 & 1 & 2 & 6 & 5 & -1 & 1 & 2 & 0.143 \\
\hline Jun 97 & 0.1093 & 0.5485 & 0.4392 & 1 & 0 & 3 & 1 & 1 & 2 & 1 & 0.200 \\
\hline Jul 97 & -0.1172 & -0.5019 & -0.3847 & 0 & 2 & 8 & 6 & -2 & 2 & 4 & 0.250 \\
\hline Aug 97 & -0.0725 & -0.1555 & -0.0831 & 1 & 4 & 7 & 10 & -3 & -3 & 0 & 0.000 \\
\hline Sep 97 & -0.1932 & -0.5038 & -0.3106 & 1 & 4 & 7 & 6 & -3 & 1 & 4 & 0.222 \\
\hline Oct 97 & -0.5604 & 0.0515 & 0.6120 & 5 & 4 & 14 & 12 & 1 & 2 & 1 & 0.029 \\
\hline Nov 97 & -0.3397 & -0.0117 & 0.3280 & 6 & 24 & 12 & 11 & -18 & 1 & 19 & 0.358 \\
\hline Dec 97 & -0.2960 & -0.0778 & 0.2182 & 19 & 18 & 11 & 17 & 1 & -6 & -7 & -0.108 \\
\hline Jan 98 & 0.2131 & -0.0902 & -0.3033 & 6 & 4 & 11 & 12 & 2 & -1 & -3 & -0.091 \\
\hline Feb 98 & 0.0745 & 0.0087 & -0.0658 & 9 & 4 & 15 & 14 & 5 & 1 & -4 & -0.095 \\
\hline Mar 98 & 0.0351 & -0.9247 & -0.9597 & 4 & 2 & 7 & 5 & 2 & 2 & 0 & 0.000 \\
\hline Apr 98 & 0.1503 & 0.2379 & 0.0876 & 2 & 4 & 21 & 9 & -2 & 12 & 14 & 0.389 \\
\hline May 98 & -0.0740 & 0.0352 & 0.1092 & 5 & 5 & 17 & 8 & 0 & 9 & 9 & 0.257 \\
\hline Jun 98 & -0.0260 & 0.1431 & 0.1692 & 7 & 4 & 11 & 0 & 3 & 11 & 8 & 0.364 \\
\hline \multicolumn{10}{|c|}{ Correlation Coefficient between Columns (3) and (10) } & 0.2105 & \\
\hline \multicolumn{10}{|c|}{ Correlation Coefficient between Columns (3) and (11) } & & 0.2411 \\
\hline
\end{tabular}

${ }^{\mathrm{a}}(11)=(10) /[(4)+(5)+(6)+(7)]$ 
Figure 1. Exchange Rate Level

(US \$ per 1,000 Korea won)

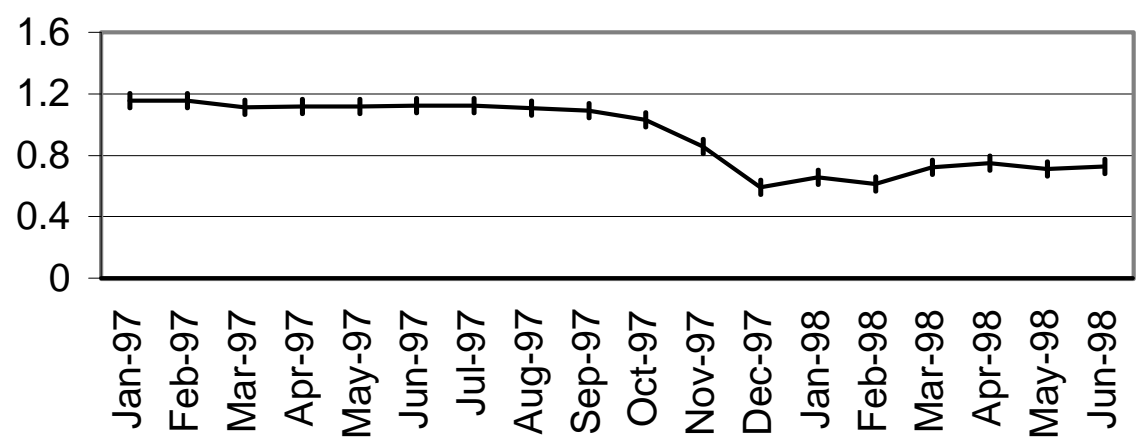

Figure 2. Stock Price Index

(KOSPI, 1980=100)

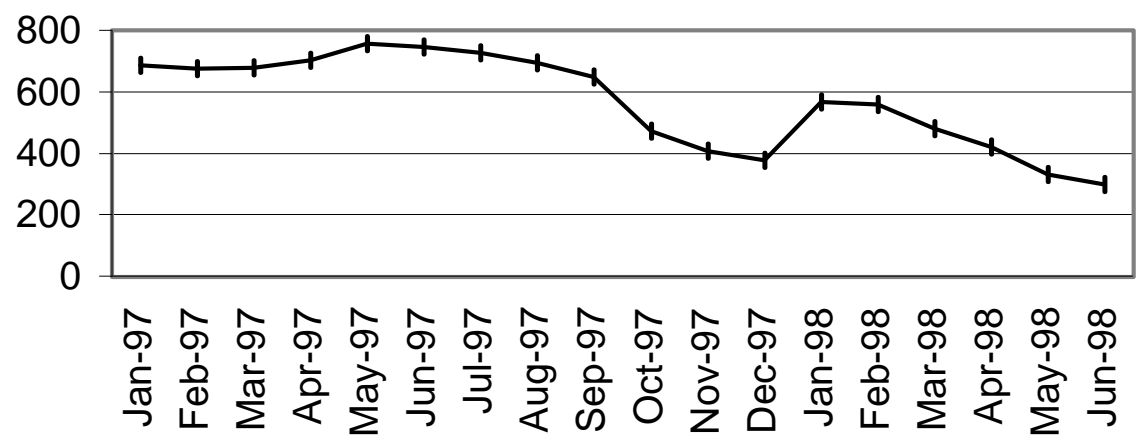

Figure 3. Current Value of US $\$ 100$

(Invested in KOSPI on January 1, 1997)

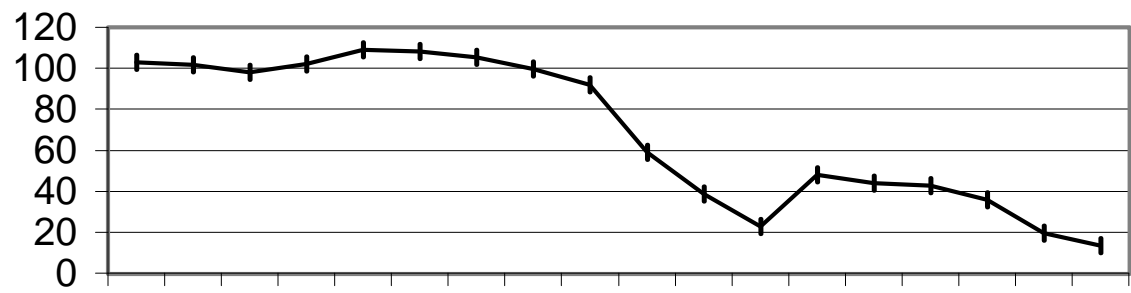

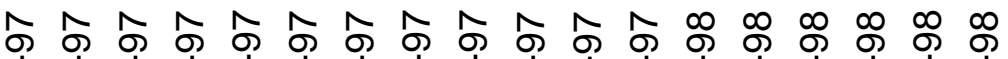

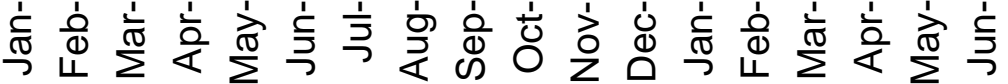

